\title{
Explaining persistence in online courses in higher education: a difference-in-differences analysis
}

\author{
Sawsen Lakhal ${ }^{1^{*}} \mathbb{0}$, Hager Khechine ${ }^{2}$ and Joséphine Mukamurera ${ }^{1}$
}

\footnotetext{
*Correspondence:

Sawsen.lakhal@usherbrooke.ca

${ }^{1}$ Faculty of Education,

Université de Sherbrooke,

2500 boulevard de l'université,

Sherbrooke, QC J1K 2R1,

Canada

Full list of author information

is available at the end of the

article
}

\begin{abstract}
The aim of this study was to verify if the UTAUT model, enriched with anxiety and factors relating to students characteristics and to the specificities of online courses, influences persistence in online courses. A theoretical model encompassing 13 variables was tested. Three moderating variables (gender, age and prior online course experience) were taken into account in the analyses. Data was collected among a sample of 759 students from Université Laval and Université de Sherbrooke using an online questionnaire. The results indicate that the main driver of persistence in online courses are: anxiety, satisfaction, effort expectancy, engagement, behavioral intention, employer encouragement, facilitating conditions and performance expectancy. The structural model was further examined according to gender, age and prior online course experience groups. Findings indicate that the model explains $21.4 \%$ to $37.1 \%$ of the variance in persistence in online courses. Moreover, as expected, the results indicated different patterns in the strength and significant relationships between groups and for the overall model, suggesting that gender, age and prior online course experience play a moderating role. The discussion links the results of this study to those of previous studies and suggests areas for improvement that could be implemented by academic administrators and instructors in order to enhance persistence in online courses.
\end{abstract}

Keywords: Persistence, Online courses, Higher education, UTAUT model, Anxiety, Moderating variables, Gender, Age, Prior online course experience

\section{Introduction}

Over the past 20 years, the number of online courses in higher education has considerably increased in North America (Myers and Schiltz 2012). The growth in the number of these courses is due to several reasons. Firstly, they meet student demands for flexible schedules. In addition, they provide better access to higher education for students who, for example, cannot attend face-to-face classes because of family or professional responsibilities (Lee 2017). Finally, they significantly lower instruction costs. Indeed, students enrolled in online courses do not need to travel any more to attend courses in person, all the while benefitting from direct or indirect interactions with instructors and other students (Wang and Hsu 2008). Moreover, online courses offered in higher education

(c) The Author(s) 2021. Open Access This article is licensed under a Creative Commons Attribution 4.0 International License, which permits use, sharing, adaptation, distribution and reproduction in any medium or format, as long as you give appropriate credit to the original author(s) and the source, provide a link to the Creative Commons licence, and indicate if changes were made. The images or other third party material in this article are included in the article's Creative Commons licence, unless indicated otherwise in a credit line to the material. If material is not included in the article's Creative Commons licence and your intended use is not permitted by statutory regulation or exceeds the permitted use, you will need to obtain permission directly from the copyright holder. To view a copy of this licence, visit http:// creativecommons.org/licenses/by/4.0/. 
present certain financial advantages for higher education institutions (Yoo and Huang 2013) and seem to be at least as effective as face-to-face courses (Bernard et al. 2004; Cavanaugh and Jacquemin 2015; Kumar et al. 2019).

However, several studies indicate that the persistence rate for online courses is low (Xavier and Meneses 2020). Moreover, these courses have a lower persistence rate than face-to-face courses (Laurie et al. 2020; Muljana and Luo 2019). Students' persistence in online courses may even be one of the greatest weaknesses associated with online learning (Herbert 2006). Levy (2007) considers the phenomenon of dropping out from online courses as a "difficult and perplexing phenomenon" (p. 187). Given the exponential increase in the number of online courses and low persistence rates in these courses, persistence should be a topic of great concern to students, instructors and higher educational institutions. As such, empirical and large-scale studies are needed to better identify its factors ${ }^{1}$ (Choi and Park 2018).

\section{Problem}

Students choose to enroll in online courses in higher education in order to attain, among other things, personal and professional goals. Their expectations are high regarding the quality of the programs and a return on their investments in terms of time and money (Downey 2000). Many efforts are deployed by higher education institutions to ensure that students enrolled in online courses are as satisfied as those who attend face-to-face courses, and to foster their persistence and academic success. More broadly, the factors of student persistence in online courses in higher education have been studied by several authors (Gazza and Hunker 2014; Laurie et al. 2020; Lee and Choi 2011; Muljana and Luo 2019; Xavier and Meneses 2020) and have been defined within some models. Regarding studies, they often examined these factors in isolation such that it is not possible to verify their combined effect on persistence and their effects on each other. As for the models on factors of persistence in online course, the most well-known are those of Ajzen (1991), Kember (1989), Park (2007), and Rovai (2003). Yet in these models, technological factors are little, or not at all, taken into account. Digital technologies play a significant role in online courses, notably in regards to their implementation, and these technological factors may play an important role in the decision to persist in or drop out from online courses (Hachey et al. 2014; Lakhal and Bazinet 2015; Lakhal 2019). Indeed, some studies identified by Lakhal and Bazinet (2015) indicate that the use of technologies (prior experience with the technologies, the variety of technology used, the use of social networks, etc.) is a significant factor in explaining persistence in online courses.

The model used in this study to encompass factors of student persistence in online courses is that of Venkatesh et al. (2003), known as the Unified Theory of Acceptance and Use of Technology model (UTAUT model), which is enriched with other factors borrowed from other models (Kember 1989; Park 2007; Rovai 2003). The UTAUT model represents a synthesis of several older models and theories and was validated in several studies within different contexts (other than persistence in online courses), including that of education (Khechine and Lakhal 2018; Lakhal and Khechine 2016, 2017;

\footnotetext{
${ }^{1}$ The more the sample is large, the more the statistical tests used to identify significant factors will be powerful, and the more the results will be precise (Field, 2013).
} 
Lakhal et al. 2013). This model is selected here because it includes technological factors that are different and complementary to other explicative models for persistence in online courses. Some factors of this model, partially present in the earlier models, have been found to be significant in explaining persistence in online courses: performance expectancy and effort expectancy (Joo et al. 2011), social influence (Kember 1989; Park 2007; Rovai 2003) and facilitating conditions (Lakhal, 2019). According to Venkatesh et al. (2003), the UTAUT model should be enriched by additional factors such as individual constructs. Among such constructs, anxiety is included in this study because it has already been integrated in previous studies evaluating either the factors of digital technology use, or the effect of digital technology use on students' academic outcomes (Bozionelos 2004; Khechine and Lakhal 2015, 2018; Lakhal and Khechine 2021; Mcilroy et al. 2007). According to these studies, anxiety seems to influence persistence in online courses (Lakhal and Khechine 2021) and presents a moderating effect on the relationship between behavioral intention and students' academic outcomes in online courses (Khechine and Lakhal 2018). These latter relationships will thus be taken into consideration in this study. The factors considered within this study that were drawn from the models proposed by Kember (1989), Park (2007) and Rovai (2003) relate to students (employment status, family responsibilities, employer encouragement, engagement to studies) and to online courses (satisfaction with the course and the learning community).

The study's objective is to identify and analyse the factors of persistence in online courses in higher education using Venkatesh et al's (2003) UTAUT model to which anxiety was added, enriched by factors relating to student characteristics and to the specificities of online courses (Kember 1989; Park 2007; Rovai 2003). Very few studies, to our knowledge, have used the model developed by Venkatesh et al. (2003) to identify factors of student persistence in online courses in higher education (Chiu and Wang 2008; Lakhal 2019; Lin 2011; Lin et al. 2013). Previous studies has mostly used other models and other factors (Lee and Choi 2011; Park 2007). Accordingly, in regards to furthering knowledge, this study will validate an integrative model in the context of online courses in higher education.

\section{Theoretical framework and the study integrative model}

The important concepts are defined in this section: online courses, persistence, factors of the UTAUT model, anxiety, those relating to student characteristics and to the specificities of online courses.

\section{Online courses}

Online courses pertain to distance learning environments using the Internet and/or Web technologies to support teaching and learning. These environments refer to all forms of learning where the various activities are distributed over time and space and do not always require the instructor or the students to be together in the same location and at the same time. According to Allen et al. (2007), a course is considered to be online when the majority of teaching and learning activities are offered online. 


\section{Persistence in online courses}

With regard to persistence in online courses, authors and the higher education institutions do not agree on one definition (Chenard et al. 2013; Laurie et al. 2020; Lee and Choi 2011; Rovai 2003; Xavier and Meneses 2020). Moreover, based on a literature review, Lee and Choi (2011) reported that many authors did not give a clear definition of persistence or dropout from online courses, and those who did were not consistent with one another. For example, in one of the studies reviewed, persistence was defined as the "intention to take more online courses" (p.597) in the future, while in another, it was about "enrolling in a course after the course census date (the end of add/drop period) and successfully completing the course with an A to C grade at the end of the term" (p.598). Others defined persistence as the students' willingness to complete the online course in which he is enrolled (DaDeppo 2009; Joo et al. 2011, 2013; Schmitz et al. 2010; Shin 2003, You 2018). Based on this, we suggest to define persistence as: (1) the intention to complete the online course in which the student is enrolled; (2) the intention to enroll in other online courses in the future; or even (3) remaining enrolled in the online course after the add/drop period. In a more recent review of the literature, Xavier and Meneses (2020) reported the same definitions of persistence.

In this study, the first definition of persistence is used: the intention to complete the online course in which the student is enrolled. We have chosen this definition for several reasons. First, approaching persistence by measuring students' intention to persist is "considered in the literature as the most proximal determinant of persistence" (Roland et al. 2018; p.216). Indeed, according to the theory of planned behavior (Ajzen 1991), the intention to adopt a behavior translates into the effective carrying out of said behavior; in this case, persistence in online courses. Many other authors, like DaDeppo (2009), Joo et al. (2011, 2013), Schmitz and Frenay (2013), Roland et al. (2018), Shin (2003) and You (2018) have also defined persistence as students' intention to persist. Second, we have conducted our study among students from two universities (Université Laval and Université de Sherbrooke), in which each of them defined persistence differently. Third, the end of add/drop period (in reference to the second definition of persistence) is not the same from one university to another. Finally, in order to collect data consistently in the two universities involved in the study, we preferred to rely on this definition of persistence (students' intention to persist) and asked students to answer to some items measuring their intention (or not) to complete the online course in which they are enrolled.

\section{Factors of the UTAUT model}

In this study's integrative model, four factors of the UTAUT model have an influence on behavioral intention to use learning management system (LMS) and on persistence in online courses: performance expectancy, effort expectancy, social influence and facilitating conditions (Venkatesh et al. 2003).

Performance expectancy can be defined as the degree to which a student believes that using a LMS will help him attain a higher level of academic performance. According to the results of a meta-analysis conducted by Šumak et al. (2011), performance expectancy has a positive effect on behavioral intention to use LMS, with a positive $\beta$ ranging from 0.13 to 0.85 , and a mean of 0.40 computed on the basis of 28 studies. This result 
Table 1 Studies on continuance intention to use/use learning management system in online courses, as reported by Lakhal and Khechine (2021)

\begin{tabular}{|c|c|c|c|c|c|}
\hline Study & Sample & & & & \\
\hline & & $P E$ & $\mathrm{EE}$ & $\mathrm{SI}$ & FC \\
\hline Alraimi et al. (2015) & $n=316,74$ countries & $.18^{* *}$ & & & \\
\hline Cheng (2014) & $\mathrm{n}=378$, Taiwan & $.22^{* *}$ & & & \\
\hline Chiu and Wang (2008) & $\mathrm{n}=286$, Taiwan & $.12^{*}$ & $.15^{*}$ & NS & NS \\
\hline Damnjanovic et al. (2015) & $\begin{array}{r}n=255 \text {, Serbia, Lithuania, } \\
\text { Bosnia and Herzegovina }\end{array}$ & $.20^{*}$ & & & \\
\hline \multirow[t]{2}{*}{ El-Masri and Tarhini (2017) } & $\mathrm{n}=418$, Qatar & $.19^{* *}$ & $.12^{* *}$ & $.14^{* *}$ & NS \\
\hline & $\mathrm{n}=389$, USA & $.20^{* *}$ & NS & NS & $.10^{*}$ \\
\hline Hsu et al. (2016) & $\mathrm{n}=119$, Taiwan & $.35^{* *}$ & $.32^{* *}$ & & \\
\hline Islam and Azad (2015) & $\mathrm{n}=185$, Finland & $\begin{array}{l}.22^{*} \\
\text { (indirect) }\end{array}$ & $.30^{* *}$ (indirect) & & \\
\hline Islam (2013) & $n=249$, Finland & $.50^{* *}$ & $.22^{* *}$ & & \\
\hline Lakhal (2019) & $\mathrm{n}=61$, Canada & NS & NS & NS & $.66^{* *}$ \\
\hline Lin et al. (2011) & $\mathrm{n}=230$, Taiwan & $.34^{* *}$ (indirect) & $.23^{* *}$ (indirect) & & \\
\hline $\begin{array}{l}\text { Mohammadyari and Singh } \\
\text { (2015) }\end{array}$ & $\mathrm{n}=34$, New Zealand & $.39^{* *}$ & NS & $.32^{* *}$ (indirect) & \\
\hline Ouyang et al. (2017) & $n=234$, China & $.20^{*}$ & & & \\
\hline $\begin{array}{l}\text { Rodríguez-Ardura and } \\
\text { Meseguer-Artola (2016) }\end{array}$ & $n=2530$, Europe & $.66^{* *}$ (indirect) & $.14^{* *}$ (indirect) & & \\
\hline Tarhini, (2017) & $n=366$, Britain & $.26^{* *}$ & $.12^{*}$ & $.23^{* *}$ & NS \\
\hline Wu and Zhang (2014) & $\mathrm{n}=284$, China & $.58^{* *}$ & $.65^{* *}$ (indirect) & $.29 * *$ (indirect) & \\
\hline Wu and Zhang (2014) & $\mathrm{n}=252$, China & $.47^{*}$ & $.32^{* *}$ (indirect) & $.13^{* *}$ (indirect) & \\
\hline Yang et al. (2017) & $\mathrm{n}=294$, China & $.29^{* *}$ & $.33^{* *}$ & & \\
\hline
\end{tabular}

$P E$ performance expectancy, EE effort expectancy, $S /$ social influence, $F C$ facilitating conditions. ${ }^{*} p<0.05,{ }^{* *} p<0.01$, NS: non-significant

continues to be confirmed by recent studies conducted within the context of online courses (see Table 1). For example, Joo et al. (2011), and Lakhal and Khechine (2021) reported a positive effect of performance expectancy on persistence in online courses.

Effort expectancy refers to the degree of ease associated with the use of LMS of online courses as perceived by the student. Šumak et al. (2011) reported that effort expectancy has a positive effect on behavioral intention to use LMS with a positive $\beta$ ranging from 0.12 to 0.41 and a mean of 0.24 , computed on the basis of the findings of 14 studies. This positive effect continues to be confirmed by recent studies (see Table 1). Moreover, Joo et al. (2011), and Lakhal and Khechine (2021) also reported positive effects of effort expectancy on persistence in online courses.

Social influence describes the degree to which students perceive that people important to them believe they should use LMS. Venkatesh et al. (2003) reported that social influence has a positive effect on behavioral intention to use digital technologies in the work environment. This finding was confirmed by a recent meta-analysis relating to, among other things, research conducted within the higher education context (Khechine et al. 2016). With regard to acceptance and use of LMS, recent studies (see Table 1) revealed that social influence has a positive effect on behavioral intention to use LMS.

Facilitating conditions refer to the degree to which the student perceives the existence of an organizational and technical structure to support the use of LMS (Lakhal 
et al. 2013). Venkatesh et al. (2003) indicated that facilitating conditions have a positive effect on the use of digital technologies within the workplace. The meta-analysis conducted by Khechine et al. (2016), based on 28 studies using the UTAUT model, also confirmed this finding. Applied to LMS, El-Masri and Tarhini (2017) revealed that facilitating conditions have a positive effect on behavioral intention. However, other studies did not reach a significant effect (see Table 1). The more a student believes that technical problems with the LMS of online courses will be solved quickly by an organizational or technical structure, the more the student will be inclined to persist in online courses. Accordingly, facilitating conditions should have a positive effect on persistence in online courses. Along these lines, Lakhal and Khechine (2021) reported a positive impact of facilitating conditions on persistence in online courses for certain sub-groups (adult students and those who have taken four or more online courses).

Behavioral intention to use LMS can be defined as the student's intention to carry out this behavior (Khechine and Lakhal 2018; Lakhal and Khechine 2016, 2017; Lakhal et al. 2013; Venkatesh et al. 2003). The findings of a study conducted by Lakhal (2019) among students enrolled in college distance courses revealed that behavioral intention has a positive effect on persistence in such courses.

\section{Anxiety}

Anxiety refers to apprehension or discomfort a student experiences with regard to using the LMS of online courses. It is a short-term worry caused by uncertainty and characterized by an emotional response, a decrease in motivation, in self-efficacy and in emotional engagement that translates into weaker academic outcomes (Abdous 2019). These negative feelings interefere with students' performance and can also have a negative impact on persistence in online courses (Chiu and Wang 2008). Abdous (2019) reported that student anxiety is inversely correlated with learning effectiveness and that the negative emotions and beliefs are important obstacles to student persistence in online courses. Chiu and Wang (2008), and Lakhal and Khechine (2021) revealed that anxiety has a negative impact on persistence in online courses. A recent study by Stiller and Köster (2016) reported similar findings. These authors who operationalized dropout as learners who showed minimal activity in the online course (logging in at least once but not having worked on any online training tasks) revealed that dropout learners showed a higher level of anxiety than persistent learners. Khechine and Lakhal (2018) also demonstrated that anxiety has a moderating effect on the relationship between behavioral intention and student outcomes in online courses.

\section{Factors relating to student characteristics}

Factors relating to student characteristics that were retained for this study are: employment status, family responsibilities, employer support and engagement.

Several previous studies considered student employment status, family responsibilities, and employer encouragement as factors related to the student or as environmental factors affecting persistence in online courses. Some studies reported a negative effect of work and family responsibilities on students retention, according to a systematic review (Bowles and Brindle 2017), others have indicated that the relationship between 
employment status (full-time, part-time, number of hours worked) and persistence is more complex, suggesting that 1 to $15 \mathrm{~h}$ of work per week could be beneficial (Riggert et al. 2006). In regard to employer encouragement or more broadly, outside support, it appears to have a positive effect on students retention (Bowles and Brindle 2017) and on students persistence in online courses (Lee and Choi 2011).

Engagement is defined as a multidimensional social process (Brault-Labbé and Dubé 2010; Kahu 2013) that is comprised of three dimensions: emotional, cognitive, and behavioral (Fredricks et al. 2004). In this study, we define engagement by the emotional dimension, which refers to the student's interest in his studies and his enthusiasm towards them. This dimension is responsible for triggering the engagement process (Brault-Labbé and Dubé 2010). Positive emotional engagement reinforces students' connection to the course and program, influences the manner in which they complete learning activities and has a positive effect on persistence in online courses (Halverson and Graham 2019; Mandernach 2015; Rovai 2003).

\section{Factors relating to the specificities of online courses}

Factors relating to the characteristics of online courses pertain to student satisfaction and learning community (Kember 1989; Park 2007; Rovai 2003). In regards to student satisfaction, it is defined in this study as elements that foster general feelings of wellbeing in online courses, from both a technological and pedagogical stance (Lakhal et al. 2014). It refers to students' perception of their learning experience and the value they attribute to online courses (Kuo et al. 2013). According to Park and Choi (2009), student satisfaction has a positive effect on persistence in online courses. This finding is confirmed in several studies (Garratt-Reed et al. 2016; Levy 2007; Müller 2008; Park and Choi 2009; Yang, Baldwin, et al. 2017; Yang, Shao, et al. 2017). Students are less likely to withdraw from their courses when they are satisfied and when their courses are perceived as relevant to their everyday life experiences (Joo et al. 2011; Levy 2007).

Learning community is defined as a group of students led by an instructor with the aim of mastering knowledge, skills or attitudes, by interacting with and helping each other throughout the learning process. It encompasses the needs of all students, links them to each other and to instructors, and to all the resources useful for them to persevere and succeed (Rovai 2003). According to the results of previous studies in face-toface and online courses, learning community is often associated with deep and higher order learning, collaborative knowledge construction, critical discourse and reflection (Garrison 2016). Furthermore, learning communities in online courses would encompass the needs of all students, connect them to each other and to instructors, and to all the resources that they need in order to persist and succeed (Rovai 2003). In this research, we used the community of inquiry model of Garrison et al. $(2000,2001)$. This theoretical framework has shown to be useful in guiding research and practice in online and blended courses in higher education (Garrison, Cleveland-Innes and Fung 2010). According to these authors, the quality of the educational experience depends on the interaction between three types of presences: teaching, social and cognitive. The dynamics between these presences are at the heart of effective learning and a deep and meaningful educational experience (Garrison 2016). Teaching presence is reflected in the pedagogical strategies used by instructors to create enriching and challenging learning 
experiences in online courses. Social presence is about the ability of students to communicate their personal characteristics within the learning community. Cognitive presence is the ability of students to make sense of the information they receive and to confirm it through exchanges within a learning community, leading to resolution of a problem or dilemma (Akyol and Garrison 2011).

In the present study, we defined the learning community by teacher presence and cognitive presence because social presence is difficult to implement in an online course, especially in our context. In the context of our study, we surveyed students registered in online courses at Université Laval and Université de Sherbrooke in which they never had face-to-face contacts with each other and with instructors, except during the final exam at Université Laval. To our knowledge, only two previous studies have investigated the effect of teaching, social and cognitive presences on persistence in online courses, and in these two studies, social presence failed to predict persistence. In the study by Joo et al. (2011), only teaching and cognitive presences had an indirect effect on persistence in online courses. In another study by Ice et al. (2011), no significant differences between low and high disenrollment online courses were reported for the three presences. However, they revealed that four items of the community of inquiry survey related to teaching and cognitive presences accounted for a large portion of students retention in online courses.

\section{Gender, age and online course experience}

The integrative model also includes other variables that exert a moderating effect on the model's relationships: gender, age, and prior online course experience (Venkatesh et al. 2003). Venkatesh et al. (2003) reported that gender, age and experience play a moderating role in the relationship between performance expectancy, effort expectancy, social influence and facilitating conditions on the one hand, and behavioral intention to use the LMS on the other hand. Recent studies continue to confirm these findings (Khechine et al. 2014; Lakhal et al. 2013). In Rovai's (2003) model, gender and age influence student persistence in online courses. However, Rovai (2003) did not explain the nature of this relationship. According to Park (2007), there is no consensus regarding the direct influence of gender and age on persistence in online courses. Indeed, recent studies have reported contradictory findings (Mahmodi and Ebrahimzade 2015; Park and Choi 2009; Stoessel et al. 2015; Sultan and Hagger 2013). As such, Park and Choi (2009) suggest that gender and age should be considered as moderating variables. According to a review by Lee and Choi (2011), in regards to prior online course experience, studies have determined that the number of previously completed online courses is a significant predictor of persistence in online courses. Recent studies continue to confirm this finding (Hachey et al. 2014). According to Abdous (2019), the more students have experience with online courses, the lower their anxiety and the more they are inclined to learn online and to persevere. However, other studies did not find a significant relationship between previous online course experience and persistence (Stiller and Köster 2016). In this study, gender, age and prior online course experience are considered as moderating variables. A moderating variable is a qualitative or quantitative variable that affects the direction 


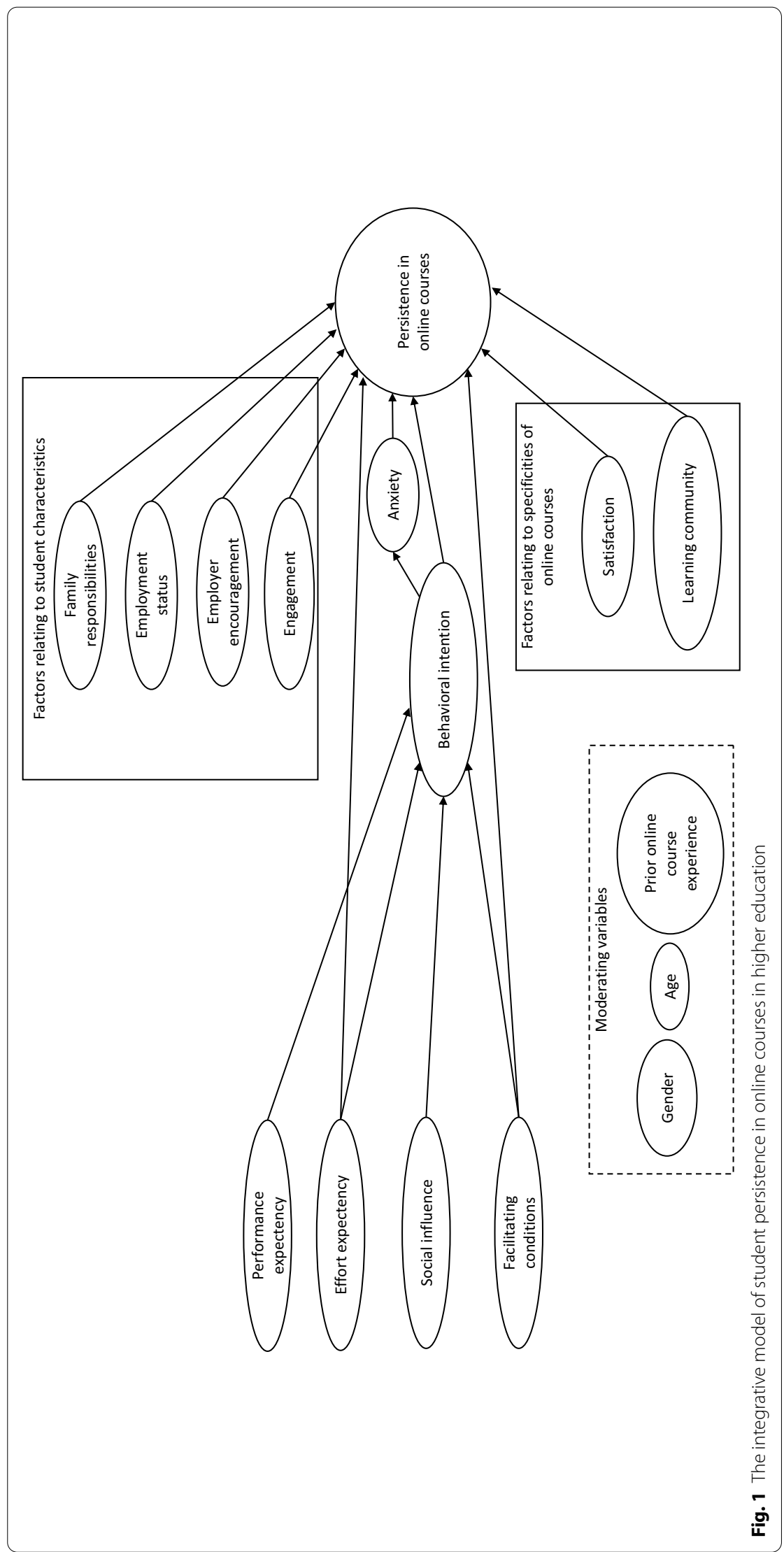


and/or the strength of the relationship between two other variables (Baron and Kenny 1986).

The study integrative model is presented in Fig. 1.

\section{Methodology}

\section{Procedure}

For the purpose of this study, ethical authorizations were requested and obtained from the research ethics committees of Université Laval and Université de Sherbrooke where data collection took place (UL-2016-035 and CER-ESS 2015-31). Mailing lists including the email addresses of all students taking online courses during the fall 2015 and winter 2016 terms were provided by Université Laval and Université de Sherbrooke and used by the researchers to contact the participants. An online questionnaire was selected because, as compared to a conventional questionnaire, this data collection method offers several advantages including: low delivery costs, ease of response transcription and scoring, short response time, ease of contacting a large number of potential respondents, and fewer errors during the transcription and coding of data since the responses are recorded into a pre-coded electronic file (Zhang 2000). Students received email invitations to participate in the study, including the link leading to the questionnaire, which was available during the last 5 weeks of the fall 2015 and winter 2016 terms. The online questionnaire took around $30 \mathrm{~min}$ to complete. Students could complete it in a continuous manner, or they could interrupt completion and return to where they left off as many times as needed. They received reminder messages during the data-collection period. Student participation was voluntary. As compensation for their time, twelve 50 \$ gift certificates were randomly drawn at the end of the data-collection periods.

\section{Participants}

Study participants were students who took online courses during fall 2015 and winter 2016 terms in two universities in Quebec, Canada. A total of 759 questionnaires were usable: 417 from Université Laval and 342 from Université de Sherbrooke. Descriptive statistics drawing the profile of participants are presented in Table 2. These statistics were computed using SPSS version 25 software.

\section{Measures}

The questionnaire had two main sections: (1) demographic questions pertaining to gender, age, prior online course experience, employment status, computer skills level, and family responsibilities; (2) items relating to the study constructs: performance expectancy, effort expectancy, social influence, facilitating conditions, behavioral intention, anxiety, employer encouragement, emotional engagement, satisfaction, learning community (teaching and cognitive presence) and persistence.

In order to operationalize the variables of this study, items were selected and adopted from previous research. Some items drawn from these previous studies were dropped or modified to adapt to the context of this study, and the scales were translated to French. All items were rated on a 7-point Likert-like scale ranging from 1 (strongly disagree) to 7 (strongly agree). Table 3 presents the sources of these items. 
Table 2 The profile of participants

\begin{tabular}{llc}
\hline & Frequency & Percent \\
\hline Gender & & 28.2 \\
Male & 545 & 71.8 \\
Female & & 39.5 \\
Age & 300 & 60.5 \\
25 years and younger & 459 & 30.6 \\
26 years and older & & 69.4 \\
First experience in an online course & 232 & \\
Yes & 527 & 46.2 \\
No & & 42.6 \\
Employment status & 351 & \\
Full time & 323 & 9.5 \\
Part time & & 68.6 \\
Computer skills & 72 & 21.9 \\
Novice & 521 & \\
Intermediate & 166 & 17.5 \\
Expert & & 31.1 \\
Family responsibilities & 133 & 51.4 \\
Not important & 236 & \\
Average important & 390 & \\
Very important & & \\
\hline
\end{tabular}

Table 3 Sources of the scales used in the study

\begin{tabular}{|c|c|}
\hline Scales & Sources \\
\hline $\begin{array}{l}\text { UTAUT model (performance expectancy, effort expec- } \\
\text { tancy, social influence, facilitating conditions and } \\
\text { behavioral intention) }\end{array}$ & $\begin{array}{l}\text { Khechine and Lakhal (2018), Khechine et al. (2014), } \\
\text { Lakhal (2019), Lakhal et al. (2013), Lakhal and Khechine } \\
\text { (2016, 2017), Venkatesh et al. (2003) }\end{array}$ \\
\hline Anxiéty & $\begin{array}{l}\text { Khechine and Lakhal (2018), Lakhal and Khechine (2021), } \\
\text { Loyd and Gressard (1984), Loyd et al. (1987) }\end{array}$ \\
\hline Employer encouragement & Heilporn and Lakhal (in revision), Kember et al. (1992) \\
\hline Engagement & Brault-Labbé and Dubé (2010) \\
\hline Satisfaction & Lakhal et al. $(2007,2014)$ \\
\hline Learning community & Heilporn and Lakhal (2020) \\
\hline Persistence & $\begin{array}{l}\text { Heilporn and Lakhal (2021), Joo et al. (2011), Lakhal } \\
\text { (2019), Strevy (2009) }\end{array}$ \\
\hline
\end{tabular}

\section{Results}

\section{Measurement model}

Given the sample size $(n=759)$, the size of the sub-groups, and the number of variables considered, the analyses were conducted using Partial Least Square techniques and algorithms. Indeed, these methods make it possible to conduct multivariate analyses with small samples (Chin 2001).

The measurement model was assessed using some criteria presented in Table 4.

Some items were removed from the model in order to satisfy the criteria presented in Table 4. After having removed these items, the model was re-assessed (Chin 2001; Gefen and Straub 2005). All of the items present significant external loading on 
Table 4 The criteria for assessment of the measurement model

\begin{tabular}{|c|c|c|}
\hline Validity and reliability & Criteria & References \\
\hline Construct validity & Loadings $\geq .70$ & $\begin{array}{l}\text { Gerbing and Anderson (1988); Hair et al. } \\
\text { (2012); Nunnally (1978) }\end{array}$ \\
\hline Internal consistency & $\begin{array}{l}\text { Cronbach Alpha }>.70 \\
\text { Composite reliability }>.70\end{array}$ & Hair et al. (2017) \\
\hline Convergent validity & Average variance extracted $>.50$ & Fornell and Larcker (1981); Nunnally (1978) \\
\hline Discriminant validity & $\begin{array}{l}\text { The square roots of the AVE }>\text { any other } \\
\text { correlation between the constructs }\end{array}$ & Fornell and Larcker (1981) \\
\hline
\end{tabular}

their respective constructs, demonstrating adequate construct validity, with loadings ranging between 0.73 and 0.98. As for internal consistency, Cronbach Alpha and composite reliability values surpass the threshold of 0.70 for all constructs (Hair et al. 2017), indicating adequate internal consistency. Convergent validity is also respected, as all of the Average variance extracted (AVE) are above 0.50 (varying between 0.70 and 1). Discriminant validity is confirmed as the square roots of AVE are greater than any other correlation between the constructs considered within this study (Fornell and Larcker 1981). Table 5 presents the results for internal consistency, and convergent and discriminant validity. The diagonal elements of the correlational matrix represent the square root of AVE.

The structural model was tested using the overall sample and for each gender, age and prior online course experience sub-group. This model includes: the indirect effects of performance expectancy, effort expectancy, facilitating conditions, behavioral intention, as well as the direct effects of effort expectancy, facilitating conditions, behavioral intention, anxiety, family responsibilities, employment status, employer encouragement, engagement, satisfaction, and learning community on persistence in online courses (see Fig. 1). These analyses were conducted using Smart-PLS version 3 software.

\section{Test of the integrative model for the overall sample}

The results of the structural model analysis (see Fig. 2) indicate that 9 paths are significant (out of a total of 15 ). The $\mathrm{R}^{2}$ coefficient of determination reveals that $24.5 \%$ of variance in persistence in online courses can be explained by the structural model's variables. In order to classify the factors of persistence in online courses in order of importance, aside the direct effects presented in Fig. 2, we computed the specific indirect effects. In order, the factors of persistence in online courses are: anxiety $(\beta=-0.28, p<0.01)$, satisfaction $(\beta=0.26, p<0.01)$, effort expectancy $(\beta=0.12$, $p<0.05)$, engagement $(\beta=0.10, p<0.05)$, behavioral intention via anxiety $(\beta=0.07$, $\mathrm{p}<0.01)$, employer support $(\beta=-0.06, \mathrm{p}<0.01)$, facilitating conditions via behavioral intention and anxiety $(\beta=0.02, \mathrm{p}<0.01)$, effort expectancy via behavioral intention and anxiety $(\beta=0.01, \mathrm{p}<0.05)$, and performance expectancy via behavioral intention and anxiety $(\beta=0.01, \mathrm{p}<0.05)$.

Insert Fig. 2 here. 


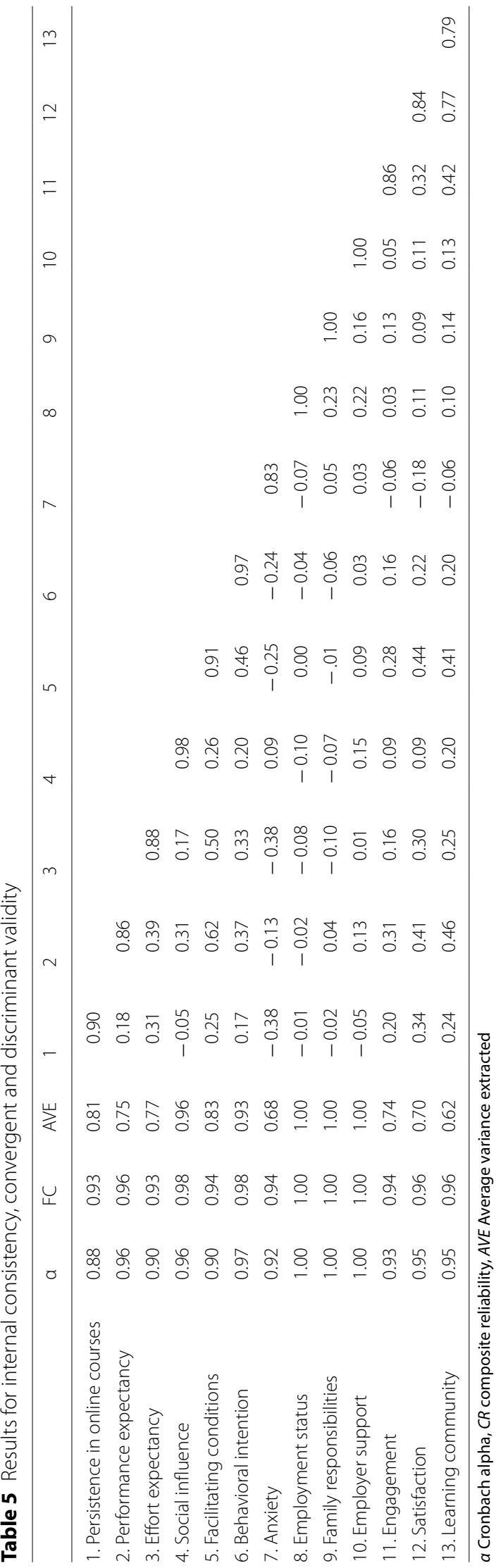




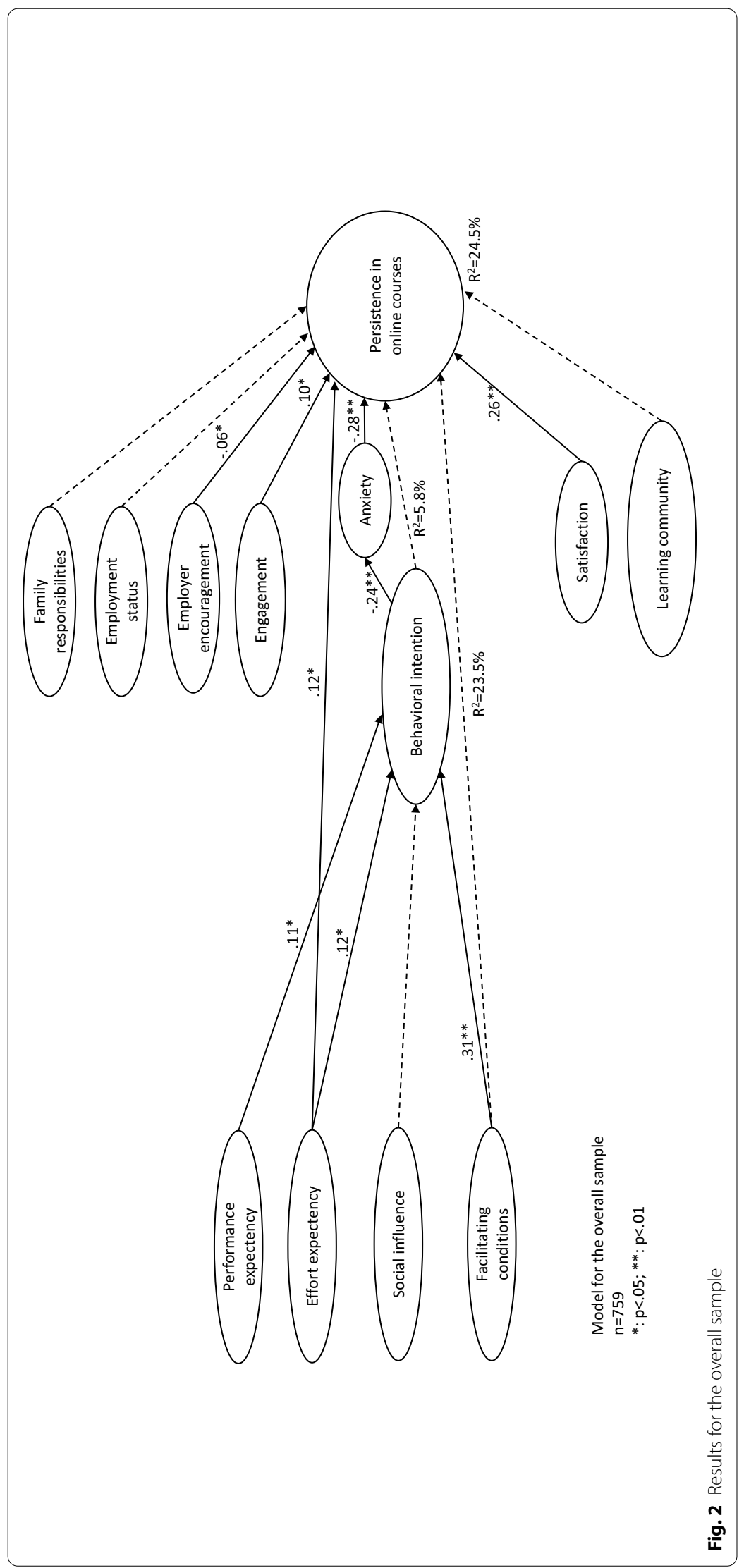


Test of the integrative model for each sub-group according to gender, age and prior online course experience

In order to verify if gender, age and prior online course experience play a moderating role in persistence, the study sample was divided into 2 groups according gender: men $(n=214)$ and women $(n=545)$. Two age groups were also created: students of 25 years and younger $(n=300)$ and students of 26 years and older $(n=459)$. Finally, the sample was divided into two groups according to prior online course experience: students with no experience $(n=232)$ and students with experience $(n=527)$. The model analyses were conducted for each sub-group using Smart-PLS software.

The $\mathrm{R}^{2}$ coefficients of determination for the sub-groups are different and superior to those obtained for the overall sample, except for the women $(24 \%)$ and students with prior online course experience (21.4\%). The results found in Figs. 3, 4, 5, 6, 7 and 8 indicate that the sub-group models present significant paths that differ from those of the overall sample. Moreover, these significant paths are different between the subgroups according to gender, age and prior online course experience. As such, these variables play a moderating role in persistence in online courses.

Like for the overall sample, in order to classify the factors of persistence in online courses in order of importance, aside the direct effects presented in Figs. 3, 4, 5, 6, 7 and 8 , the specific indirect effects were computed. For the men, the factors of persistence in online courses are, in order of importance (Fig. 3): anxiety $(\beta=-0.32$, $\mathrm{p}<0.01)$, satisfaction $(\beta=0.27, \mathrm{p}<0.05)$, employer encouragement $(\beta=-0.14$, $\mathrm{p}<0.01)$, and behavioral intention via anxiety $(\beta=0.05, \mathrm{p}<0.05)$. For women, the factors are, in order of importance (Fig. 4$)$ : anxiety $(\beta=-0.26, p<0.01)$, satisfaction $(\beta=0.25, p<0.01)$, engagement $(\beta=0.14, p<0.01)$, effort expectancy $(\beta=0.11$, $\mathrm{p}<0.05)$, behavioral intention via anxiety $(\beta=0.07, \mathrm{p}<0.01)$, facilitating conditions via behavioral intention and anxiety $(\beta=0.02, \mathrm{p}<0.05)$ and social influence via behavioral intention and anxiety $(\beta=0.01, \mathrm{p}<0.05)$.

In regards to students 25 years of age and younger, the factors of persistence in online courses are, in order of importance (Fig. 5): anxiety $(\beta=-0.45, \mathrm{p}<0.01)$, satisfaction $(\beta=0.16, \mathrm{p}<0.05)$, behavioral intention via anxiety $(\beta=0.14, \mathrm{p}<0.01)$, employment status $(\beta=-0.13, \mathrm{p}<0.05)$, facilitating conditions $(\beta=-0.12, \mathrm{p}<0.05)$, facilitating conditions via behavioral intention and anxiety $(\beta=0.04, \mathrm{p}<0.05)$ and effort expectancy via behavioral intention and anxiety $(\beta=0.03, p<0.05)$. For students of 26 years and older, these factors are, in order of importance (Fig. 6): satisfaction $(\beta=0.31, p<0.01)$, anxiety $(\beta=-0.20, p<0.01)$, engagement $(\beta=0.12, p<0.05)$, employer support $(\beta=-0.09, p<0.01)$, behavioral intention via anxiety $(\beta=0.04$, $\mathrm{p}<0.05)$, facilitating conditions via behavioral intention and anxiety $(\beta=0.01$, $p<0.05)$, and performance expectancy via behavioral intention and anxiety $(\beta=0.01$, $\mathrm{p}<0.01)$.

Finally, in regards to prior online course experience, for the student group without previous experience, the factors in order of importance are (Fig. 7): anxiety $(\beta=-0.42, \mathrm{p}<0.01)$, satisfaction $(\beta=0.18, \mathrm{p}<0.05)$, engagement $(\beta=0.10, \mathrm{p}<0.05)$, employer encouragement $(\beta=-0.09, \mathrm{p}<0.05)$ and behavioral intention via anxiety $(\beta=0.07, p<0.05)$. For those with prior online course experience, the factors in order of importance are (Fig. 8): satisfaction $(\beta=0.30, p<0.01)$, anxiety $(\beta=-0.22$, 


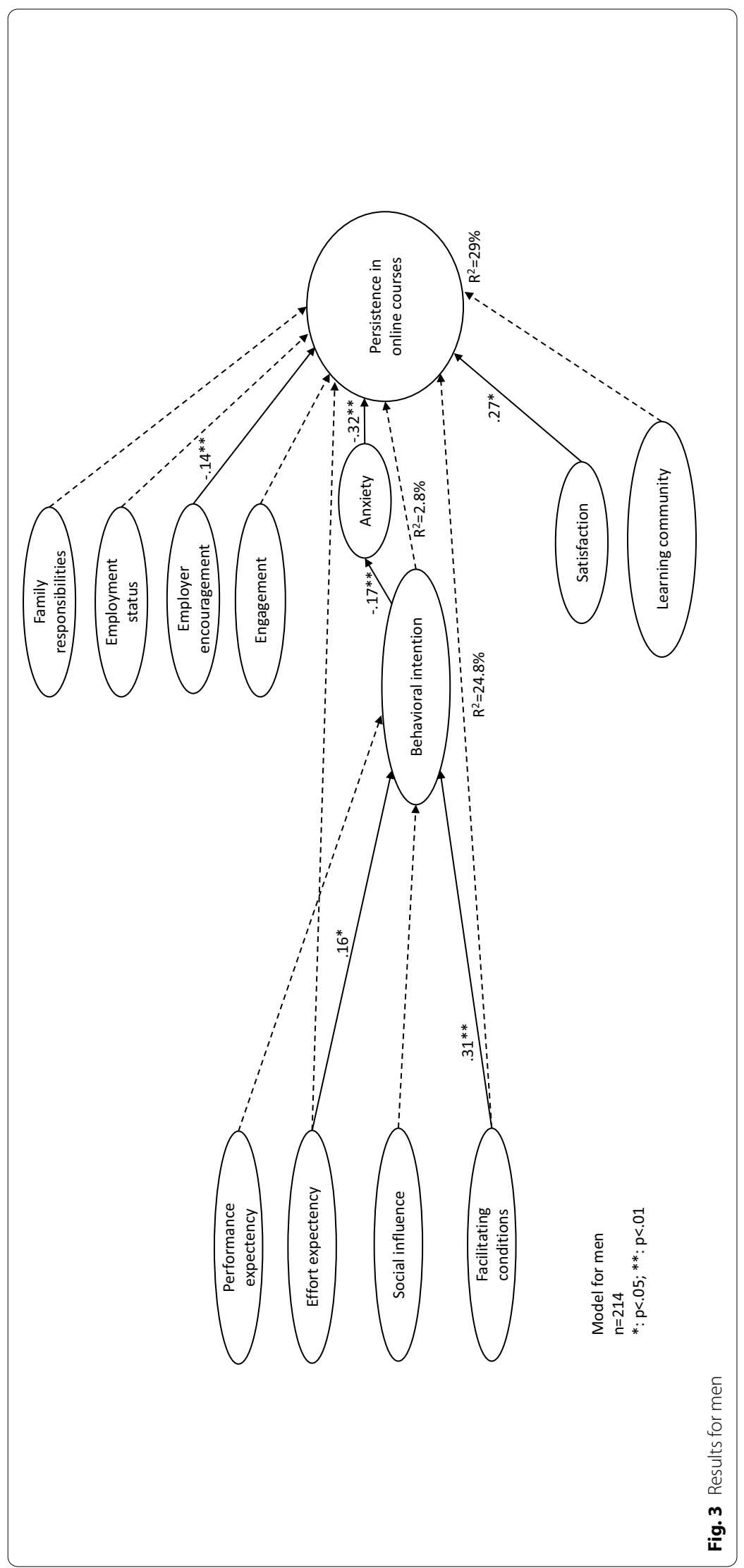




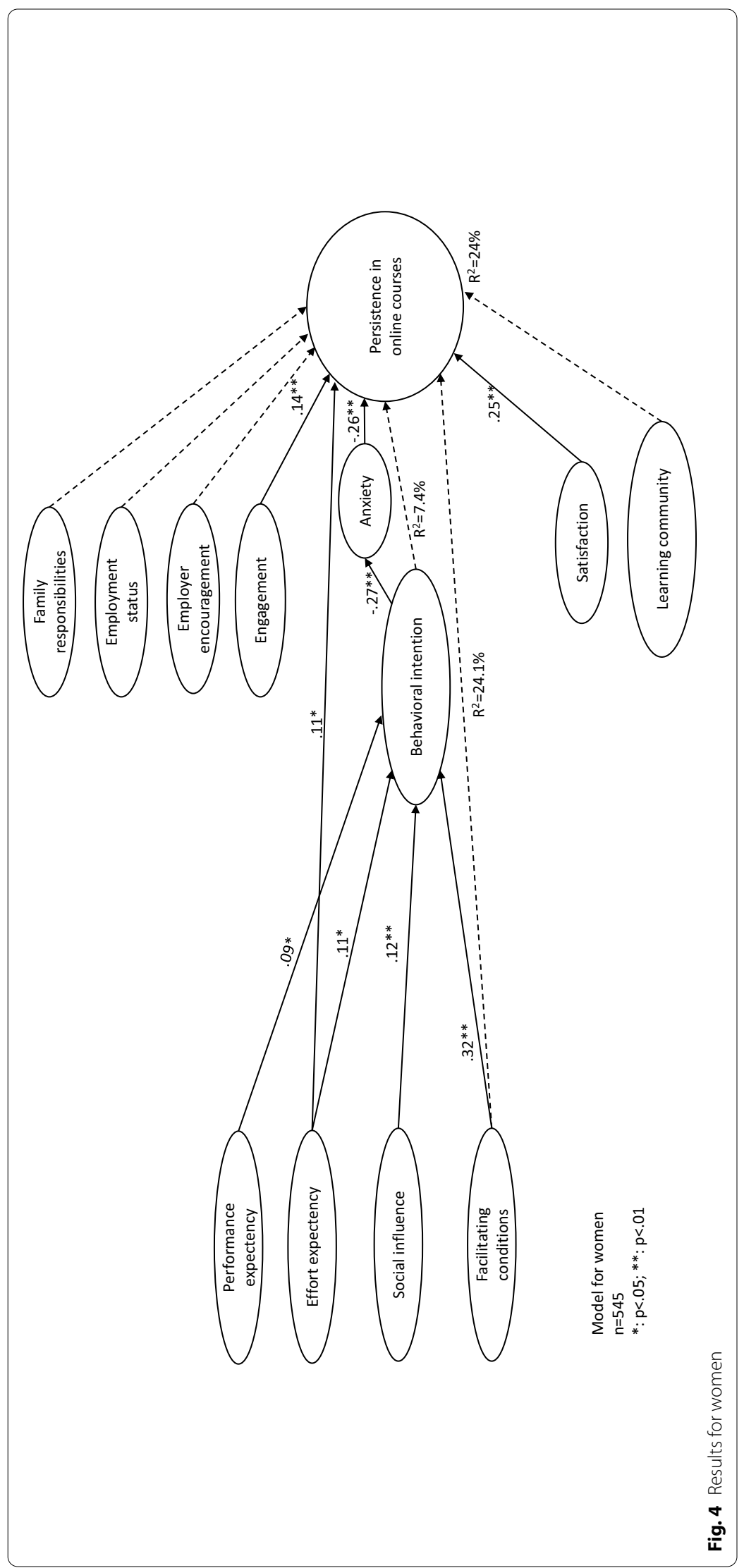




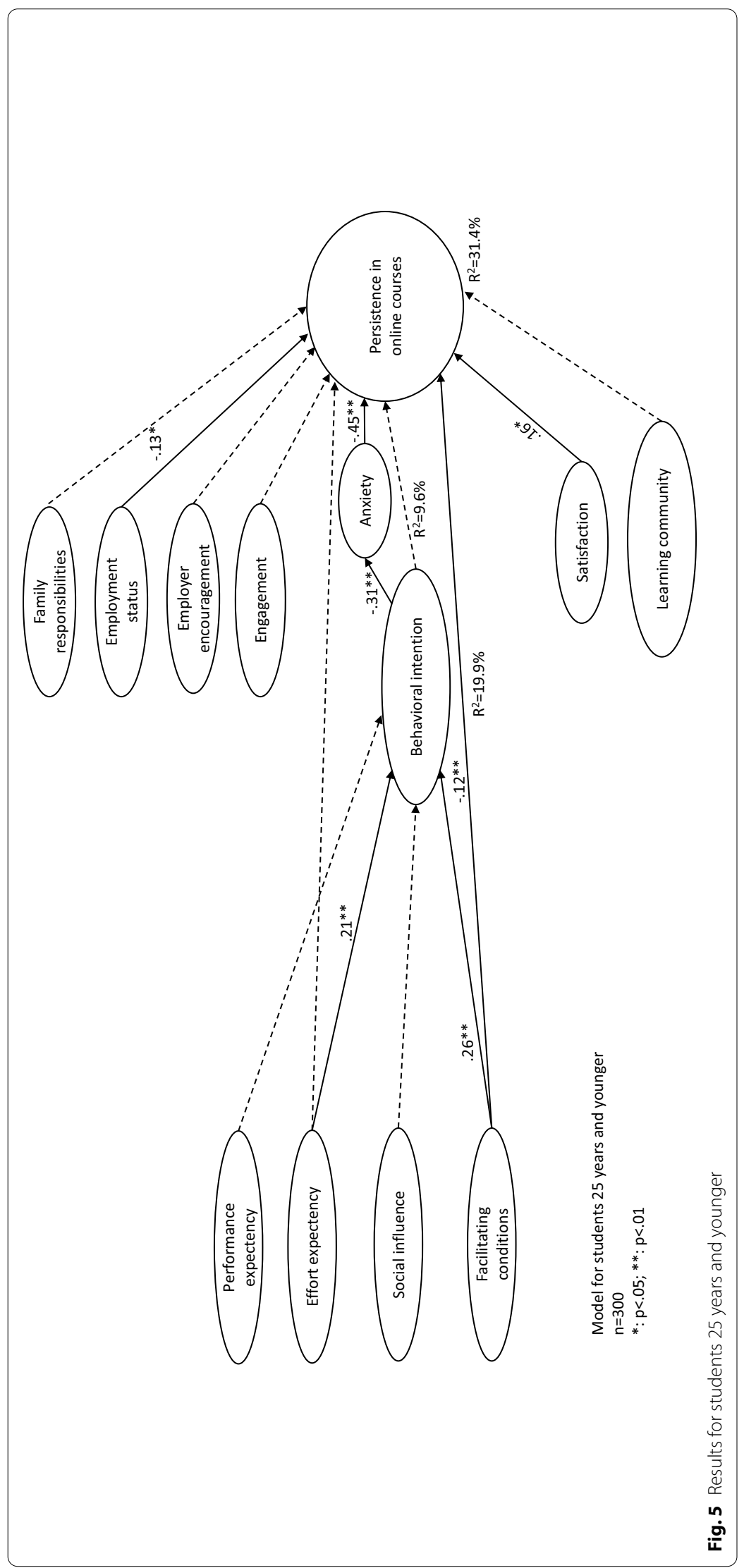




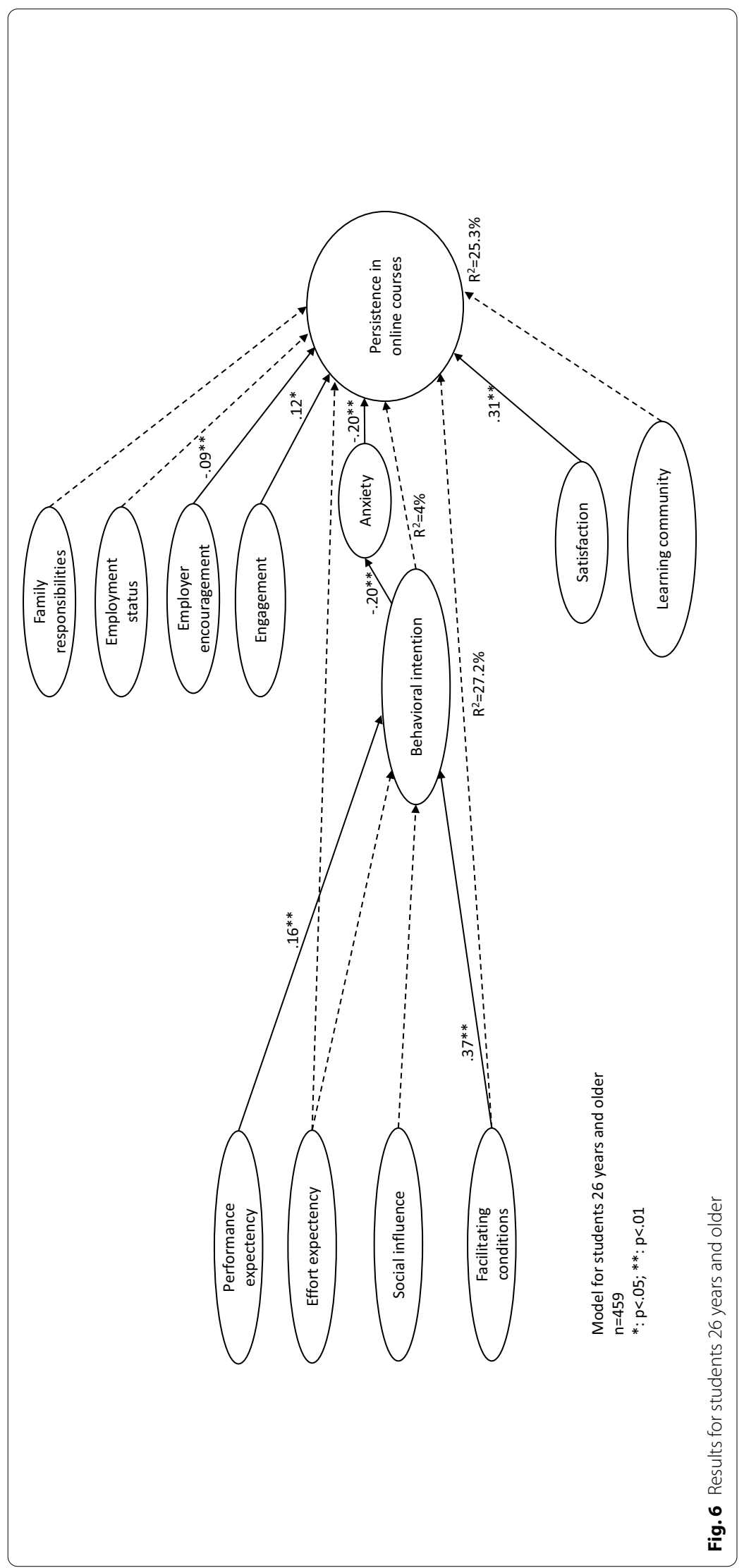




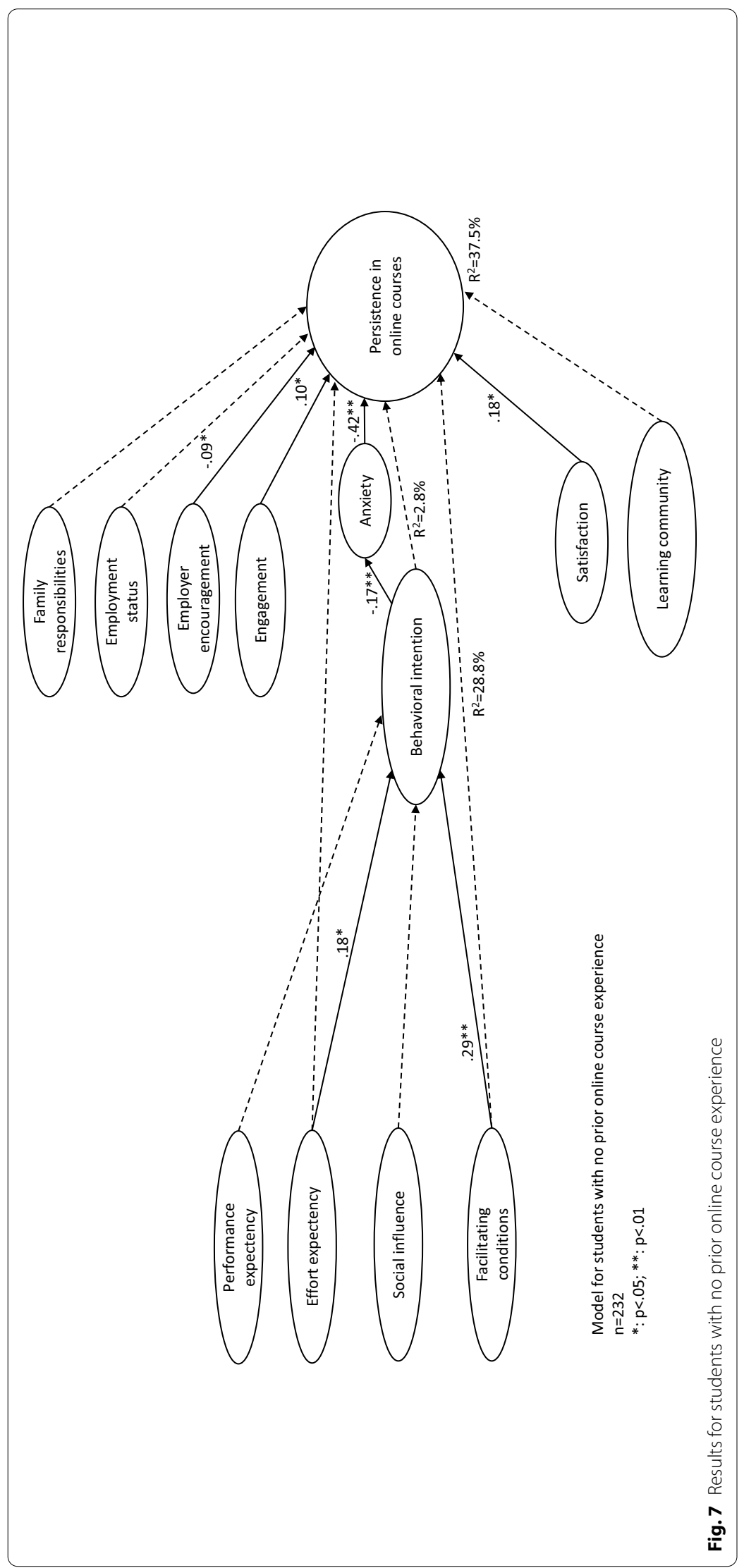




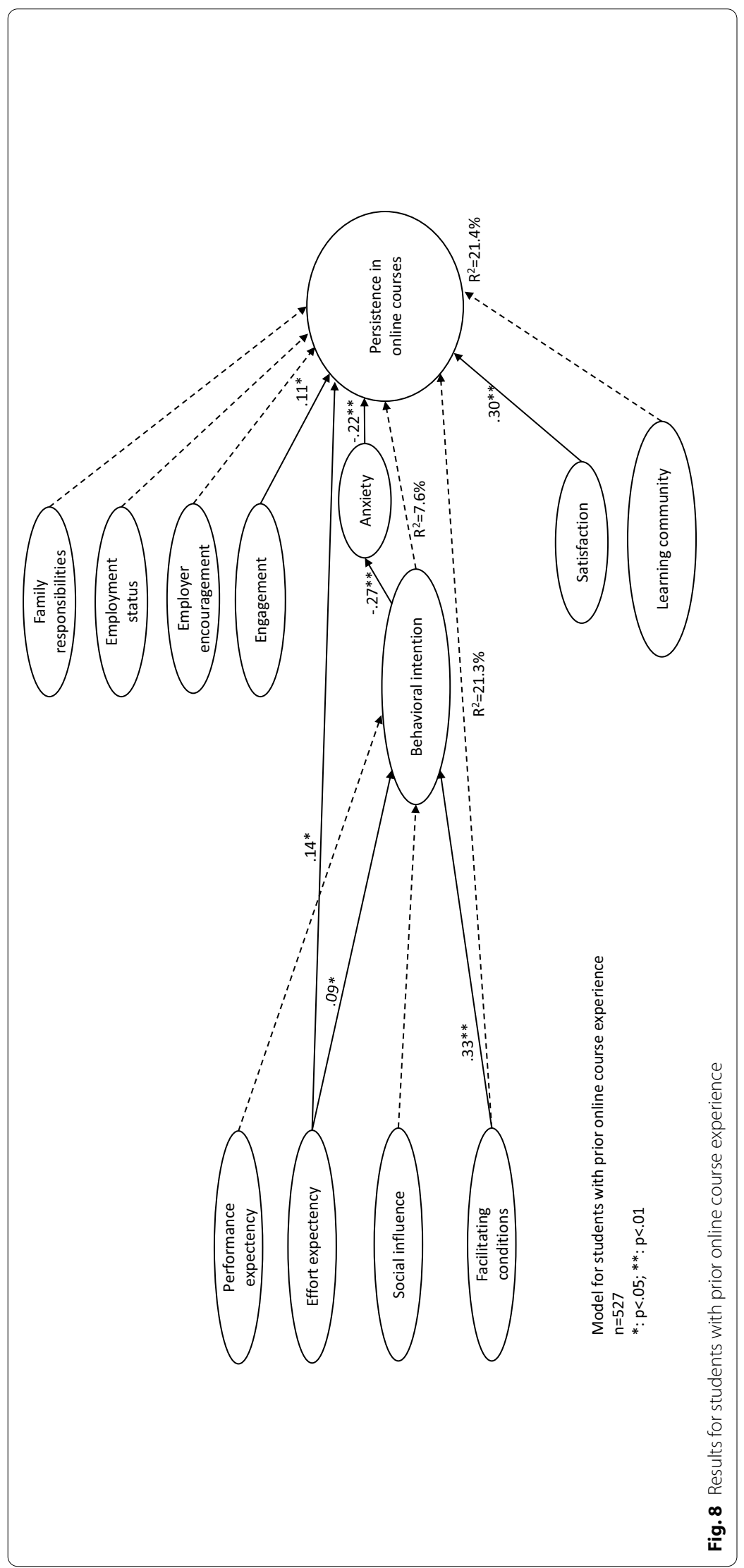


$\mathrm{p}<0.05)$, effort expectancy $(\beta=0.14, \mathrm{p}<0.05)$, engagement $(\beta=0.11, \mathrm{p}<0.05)$, behavioral intention via anxiety $(\beta=0.06, \mathrm{p}<0.05)$, and facilitating conditions via behavioral intention and anxiety $(\beta=0.02, \mathrm{p}<0.05)$.

\section{Discussion}

The study's objective was to identify and analyze the factors of persistence in online courses in higher education. These factors were drawn from Venkatesh et al.s (2003) UTAUT model (performance expectancy, effort expectancy, social influence, facilitating conditions and behavioral intention) to which anxiety was added, and enriched by factors pertaining to student characteristics (family responsibilities, employment status, employer encouragement, and engagement) and online course characteristics (satisfaction and learning community) (Kember 1989; Park 2007; Rovai 2003). Gender, age, and prior online course experience were assessed as moderating variables because they are considered by the UTAUT model to be moderating variables (Venkatesh et al. 2003) and because some authors suggest using them as such since there is no consensus regarding the direct influence of gender and age on persistence in online courses (Park 2007; Park and Choi 2009). The integrative model proposed in this study is innovative because, to our knowledge, no other study has used the UTAUT model enriched by anxiety and other factors drawn from other models (Kember 1989; Park 2007; Rovai 2003) to explain persistence in online courses. This integrative model was tested for the overall sample and each sub-group. The results of this study indicate that it is possible to empirically explain student persistence in online courses, as is also true for the model tested on the different student sub-groups. It should be noted that the sub-groups presented significant paths that differed from each other. Finally, in the integrative model, the empirical results indicate that the two most important explanatory factors in persistence in online courses are anxiety (added to the UTAUT model) and satisfaction (as a specific characteristic of online courses) for the overall sample as well as for all sub-groups. However, the discussion is structured according to blocks of factors, as presented within the problem and theoretical framework sections.

\section{Factors of the UTAUT model}

All factors of the UTAUT model were significant in explaining persistence in online courses. In order of importance, effort expectancy (direct and indirect effects), behavioral intention (indirect effect), facilitating conditions (indirect effect) and performance expectancy (indirect effect) have an influence on persistence in online courses. Social influence was, however, significant only for the women's sub-group, corroborating the findings of Lakhal et al. (2013) and Venkatesh et al. (2003) according to which women are more sensitive than men to the influence of their entourage.

Researching student persistence in online courses using the UTAUT model is thus relevant, as already confirmed by Lakhal (2019) among college students $(n=61)$. The factors of the UTAUT model have shown themselves to be useful, either directly or indirectly, to explain persistence in online courses, after anxiety and satisfaction. Moreover, these factors do not always present the same significant effects from one sub-group to another 
Effort expectancy, which refers to the degree of perceived ease of use of the LMS, has a direct effect on persistence among women and students with prior online course experience, and an indirect effect for all sub-groups except older students (over the age of 25). These findings partially corroborate those of Joo et al. (2011) according to whom effort expectancy has an indirect effect on persistence (via student satisfaction). For these subgroups, efforts should be made to ensure that the LMS is easy to use. In this regard, the structure and organization of the platform should not change from one online course to another within the same program or faculty. The resources should be put at the same place (course preparation module, course outline, discussion forums, links toward synchronous sessions, etc.) in order to facilitate navigation and reduce students' efforts to adapt from one course to another. Effort expectancy did not present any significant effect (either direct or indirect) on student persistence among students over the age of 25. These findings corroborate those obtained by Lakhal (2019) who reported no significant indirect effect (via behavioral intention) of effort expectancy on persistence.

Behavioral intention to use the LMS has an indirect effect on persistence via anxiety for the overall sample and all sub-groups. The more students use the LMS, the less anxious they are and the more they persevere in online courses. In order to increase LMS use and accordingly decrease anxiety and improve persistence, instructors could make the interface more attractive and integrate engaging and motivating activities.

In regards to facilitating conditions, which refer to students' perception of the existence of an organizational and technical structure likely to assist them when faced with problems using the LMS, they have an indirect effect on persistence in online courses for the overall sample and all sub-groups, as well as a direct effect for younger students. These findings corroborate those reported by Lakhal (2019). As such, the results of this study support the fact that students' learning experience could be improved or diminished depending on the support offered by the institutions or the instructors to facilitate use of the LMS.

Performance expectancy, which refers to the degree to which a student believes that using a LMS will help him attain a higher level of academic performance, has an indirect effect on persistence in online courses for the overall sample, women, and older students. These findings corroborate those reported by Joo et al. (2011) according to whom performance expectancy has an indirect and positive effect on persistence in online courses. However, these findings provide further nuance to those of Lakhal (2019) who found the relationship between performance expectancy and persistence in online courses to be non-significant, because in the latter study, given the small sample size, the author was not able to conduct sub-group analyses according to course modality, gender or age. In order to increase persistence in online courses, instructors could work on improving students' pedagogical perception of the MLS by integrating activities aiming to make them active in their learning, for example by allowing interactions and co-construction of knowledge with colleagues via the platform, by integrating a quiz after each module, etc.

\section{Anxiety}

In regards to anxiety, this study's findings corroborate those of Bozionelos (2004) and Mcilroy et al. (2007) according to which anxiety renders students less inclined to use 
digital technologies, and more particularly the LMS in this study, and consequently to not persevere in online courses. More recently, a study by Stiller and Köster (2016) revealed that drop-out students showed higher level of anxiety and more negative attitude towards computers than persistent ones. Along the same lines, Barbeite and Weiss (2003) observed that anxiety is reflected by an aversion to the use of the Internet. In university settings, Mcilroy et al. (2007) reported a negative relationship between anxiety and the use of digital technologies, whereby students presenting high levels of anxiety are less likely to use the digital technologies available to them because they adopt avoidance behaviors as a strategy for adapting to anxiety-provoking situations (Rachman 1998). Once accustomed to the use of digital technologies, anxiety levels decrease, which leads to an increase in their use (Venkatesh et al. 2003). The results of our study indicate that this factor is especially important among younger students ( 25 years and younger) and for those without prior online course experience. Yet, according to Prensky's (2001) theory, digital natives are more at ease and inclined to learn with digital tools than older students. The results of this study contradict this theory and corroborate findings from a large-scale study conducted among college students (Roy et al. 2018) according to which the relationships between different generations and the use of digital technologies for learning purposes is complex. As such, attention should be paid to students belonging to these two sub-groups. According to Abdous (2019), student anxiety is due to various reasons such as a lack of clear instructions on how to use the LMS, notably for those who lack computer skills. Paired with the difficulty of online course content and the student's workload, anxiety would be further increased by a weaker mastery of the LMS. In order to remediate this situation, student computer skills should be assessed at the beginning of online courses in order to assist those who do not possess the skills required to use the LMS, and thus contribute to reducing their anxiety levels. Ideally, at the beginning of an online course, students' computer skills should be similar; otherwise, some students may need to spend more time improving these skills, which could discourage them and lead them to drop out from the online course. Videos could be developed to enable students to learn these skills on their own. Orientation sessions could also be planned before enrolment in online courses in which students could familiarize themselves with the technical requirements and skills and behaviors necessary to successfully complete an online course (Cho 2012; Eliasquevici et al. 2017; Gaytan 2015; Müller 2008).

\section{Factors relating to student characteristics}

Among the factors relating to student characteristics, engagement and employer support were significant, although employment status had a negative effect on persistence for students 25 years of age and younger. Family responsibilities had no effect on persistence in online courses.

Engagement has a positive effect on persistence in online courses. This result is obtained for all sub-groups, except among men and younger students (25 years and younger). It corroborates findings of previous studies (Halverson and Graham 2019; Mandernach 2015; Rovai 2003). In order to improve student engagement, active learning strategies could be used by instructors, such as using short video recordings on course content and including reflective questions, examples from everyday life or professional practice, a reflective journal, practical exercises, problem-solving, simulations, 
and authentic and peer assessments (Binnewies and Wang 2019). Instructors could also increase opportunities for interactions (1) between students, using icebreaking activities, collaborative work, peer presentations and assessments, etc.; (2) with the instructor by means of frequent posts via email or the discussion forum, feedback using different modalities such as text, audio and video; and (3) with content using content-oriented discussions, presentation of course content in different formats and the application of course content to realistic situations (Bolliger and Martin 2018; Watts 2016).

Employer support has a negative effect on persistence in online courses. This finding was also obtained for men, students 26 years of age and older, and those without prior online course experience. This finding is surprising and contradicts those of previous studies in which outside encouragement and support has a positive effect on persistence (Kember 1989; Lee and Choi 2011). This result may be explained by the fact that employers' encouragement to complete an online course is not necessarily accompanied by the emotional or logistic support that students may need to persevere. This could also be explained by the fact that the enrollment in online courses is a direct or indirect request or a professional obligation and not students' choice. Consequently, students may not be emotionally engaged, which leads them to drop out from online courses.

\section{Factors relating to the specificities of online courses}

Student satisfaction was important in explaining persistence in online courses. In this regard, student satisfaction depends on several factors including the quality of instructors (communication, feedback, preparation, knowledge of the discipline, teaching and learning methods used, motivation, accessibility and professionalism), the digital technologies used to implement the online courses, and opportunities to interact with the instructor and other students (Fabry 2012; Téo and Wong 2013). These findings corroborate those of several previous studies in which student satisfaction has a positive effect on persistence in online courses (Choi and Park 2018; Garratt-Reed et al. 2016; Joo et al. 2011; Levy 2007; Müller 2008; Park and Choi 2009; Yang, Baldwin, et al. 2017; Yang, Shao, et al. 2017). The findings of this study indicate that the influence of student's satisfaction on persistence in online courses is greater among older students (26 years of age and older) and for those with prior online course experience. These findings further our understanding of previous studies results as it was possible to examine the effect of satisfaction within other sub-groups. This was not possible in other studies such as the one by Choi et Park (2018), since their sample was exclusively comprised of students older than 25 years of age. As such, special attention should be paid to students with these characteristics. An increase in student satisfaction could be made possible by, for example, by introducing more interactions and rapidly providing feedback to students (Choi and Park 2018; Croxton 2014; Sun et al. 2008), creating learning communities, using a diversity of pedagogical strategies to meet the various needs of the students (Kranzow 2013), implementing more flexibility and diversity in learning and assessment activities, and ensuring the quality of the digital technologies used (Sun et al. 2008). Moreover, some students' characteristics have an impact upon their satisfaction (Kauffman 2015), such as self-regulation abilities, time-management, self-reflection, etc. These characteristics could be acquired during the online course or during orientation sessions, acting as prerequisites to online course enrollment. 
The second factor relating to the specificities of online courses taken into account in the integrative model is that of learning community. This factor was non-significant in explaining persistence in online courses. This finding could be explained by the inclusion of satisfaction within the model. Indeed, the correlation between learning community and persistence in online courses is significant $(r=0.24$, see Table 5), while learning community and satisfaction is significantly and highly correlated $(r=0.77$, see Table 5), as learning community has a positive effect on satisfaction (Kranzow 2013). If the satisfaction variable had not been included in the model, learning community would probably have been among the most important factors explaining persistence in online courses. In order to foster student persistence in online courses, instructors could develop a learning community within their course. Learning communities are reputed to decrease students' isolation and encourage interactions and engagement in their learning as well as in depth learning (Garrison et al. 2000, 2001; Kranzow 2013). The model proposed by Garrison et al. $(2000,2001)$ could act as a guide by ensuring that teaching and cognitive presences are fostered given that social presence is more difficult to implement in online courses.

\section{Recommendations for effective online courses}

This study opened to several recommendations on the factors considered in the integrated model, which are summarized as follows. First, effort should be made to ensure that LMS in online courses are easy to use. For example, the structure and organization of the LMS could be the same from one course to another within the same program or faculty. The resources should be put at the same place in order to facilitate navigation and reduce students' efforts to adapt from one course to another. Second, the interface of LMS should be made more attractive and should integrate more engaging and motivating activities and resources, such as reflective journals and questions, practical exercises, problem solving, simulations, authentic and peer assessments, short video recordings on course content and examples from everyday life or professional practice. Third, the higher education institution and the instructors should provide support to facilitate the use of LMS and more broadly the technologies in online courses, in order to reduce students anxiety. To this end, videos could be developed to enable students to improve their technological skills on their own. Orientation sessions could also be planned before enrolment in online courses in which students could develop these skills. Fourth, instructors should work on improving pedagogical perception of LMS in online courses by integrating activities aiming to make students active in their learning and to increase opportunities for interactions between students (by using collaborative activities, peer presentations and peer assessments, by allowing interactions and co-construction of knowledge with colleagues via the platform), with the instructor (by using frequent posts and timely feedback) and with course content (by using contentoriented discussions, and different formats for content presentation). Finally, in order to increase student satisfaction in online courses, instructors could use a diversity of pedagogical strategies to meet students' various needs, implement more flexibility and diversity in learning and assessment activities, and ensure the quality of the digital technologies used. Moreover, instructors could develop a learning community within their 
online courses. These learning communities are reputed to decrease students' feeling of isolation and encourage deep learning.

\section{Conclusion}

This study's objective was to identify and analyse factors of persistence in online courses in higher education using the UTAUT model enriched by anxiety and factors relating to students and to the specificities of online courses. Accordingly, this study tested an integrative model comprised of 13 variables among a large sample of students from Université Laval and Université de Sherbrooke in the province of Quebec, Canada. This integrative model is innovative as no other previous study has considered the structure of relationships proposed to explain persistence in online courses. The study's findings indicate that it is possible to provide an empirical explanation of student persistence in online courses. The results reveal that the factors that have un effect on persistence in online courses are anxiety (negative), satisfaction (positive), effort expectancy (positive), engagement (positive), behavioral intention (positive), employer encouragement (negative), facilitating conditions (positive) and performance expectancy (positive). The integrative model was then tested on sub-subgroups relating to gender, age and prior online course experience. The results suggest that these variables play a moderating role.

The study results reveal that persistence in online courses is a complex process, directly or indirectly impacted by a multitude of factors both technological (UTAUT model) and specific to students or online courses. Knowledge derived from these findings is important for academic administrators and instructors. In order to foster student persistence in online courses, several strategies were discussed according to each factor, notably in regards to the most significant factors - student anxiety and satisfaction. Academic institutions would be justified in adopting these strategies in order to offer students equal chances of persevering in their online courses. For example, they could offer orientation sessions for those who do not possess the skills required to use the digital tools available to them in the online course, to implement means to ensure teaching and cognitive presences which are likely to increase student satisfaction, etc.

\section{Limitations}

It should be noted that this study has some limitations. Firstly, the sample was one of convenience. Even though its size meets the recommended standards to conduct the analyses (Chin 2001), we only accessed the perceptions of those students who responded to the online questionnaire. There could be some speculation as to differences between those who responded and those who did not. Consequently, the study findings should be generalized with caution and the study should be replicated among other sizeable student samples to verify the stability of the obtained results. Moreover, data collection was conducted during the five final weeks of the autumn 2015 and winter 2016 terms. Those who participated in the study are those who were most likely to persevere in their online course. We were not able to reach those who had already dropped out. A future study could consider distributing the questionnaire two or more times over the course of the term in order to measure the evolution of student responses over time, including that of students who drop out from the course. Furthermore, the proposed items were very generically phrased in order to be independent of the disciplines taught in online 
courses. A future study could use discipline as a moderating variable and comparisons between disciplines would thus be possible in order to nuance the results of this study. Finally, persistence in online courses is explained by $24.5 \%$ of the model's variance. However, this coefficient of determination increases for some sub-groups (31.4\% for younger students and $37.5 \%$ for students without prior online course experience). Other factors could be added to the model in future studies in order to increase its explanatory power.

\section{Authors' contributions}

$\mathrm{SL}$ was the principle researcher in this project. She supervised all the steps of the research: conception and design of the work, data collection, analysis and interpretation of data and writing. HK supervised the conception and design of the work, and data collection. She also has substantively revised the manuscript. JM has substantively revised the manuscript. All authors read and approved the final manuscript.

\section{Funding}

This study has been funded by the Fonds de Recherche Société et Culture of the Government of Quebec, Canada. The funding body did not have any role in the design of the study and collection, analysis, and interpretation of data and in writing the manuscript.

\section{Availability of data and materials}

The datasets generated during and/or analysed during the current study are available from the corresponding author on reasonable request.

\section{Declaration}

\section{Competing interests}

The authors declare that they have no competing interests.

\section{Author details}

${ }^{1}$ Faculty of Education, Université de Sherbrooke, 2500 boulevard de I'université, Sherbrooke, QC J1K 2R1, Canada. ${ }^{2}$ Faculty of Business Administration, Université Laval, 2325, rue de la Terrasse, Quebec, QC G1V 0A6, Canada.

Received: 28 September 2020 Accepted: 2 March 2021

Published online: 30 March 2021

\section{References}

Abdous, M. H. (2019). Influence of satisfaction and preparedness on online students' feelings of anxiety. The Internet and Higher Education, 41, 34-44.

Ajzen, I. (1991). The theory of planned behaviour. Organizational Behavior and Human Decision Processes, 50, $179-211$.

Allen, I. E., Seaman, J. \& Garret, R. (2007). Blending in. The extent and promise of blended education in the United States. The Sloan Consortium. http://www.sloanconsortium.org/publications/survey/pdf/Blending_In.pdf

Alraimi, K. M., Zo, H., \& Ciganek, A. P. (2015). Understanding the MOOCs continuance: The role of openness and reputation. Computers \& Education, 80, 28-38

Barbeite, F. G., \&Weiss, E. M. (2003). Computer self-efficacy and anxiety scales for an Internet sample: Testing measurement equivalence of existing measures and development of new scales. Computers in Human Behavior, 20(1), $1-15$.

Baron, R. M., \& Kenny, D. A. (1986). The moderator-mediator variable distinction in social psychological research: Conceptual, strategic, and statistical considerations. Journal of Personality and Social Psychology, 51(6), 1173-1182.

Bernard, R. M., Abrami, P. C., Lou, Y., Borokhovski, E., Wade, A., Wozney, L., Wallet, P. A., Fiset, M., \& Euan, B. (2004). How does distance education compare with classroom instruction? A meta-analysis of the empirical literature. Review of educational research, 74(3), 379-439.

Binnewies, S., \&Wang, Z. (2019). Challenges of Student Equity and Engagement in a HyFlex Course. In C. N. Allan, C. Campbell, \& J. Crough (Eds.), Blended Learning Designs in STEM Higher Education: Putting Learning First (pp. 209-230). Springer.

Bolliger, D. U., \& Martin, F. (2018). Instructor and student perceptions of online student engagement strategies. Distance Education, 39(4), 568-583.

Bowles, T. V., \& Brindle, K. A. (2017). Identifying facilitating factors and barriers to improving student retention rates in tertiary teaching courses: A systematic review. Higher Education Research and Development, 36(5), 903-919.

Bozionelos, N. (2004). Socio-economic background and computer use: The role of computer anxiety and computer experience in their relationship. International Journal of Human-Computer Studies, 61 (5), 725-746.

Brault-Labbé, A., \& Dubé, L. (2010). Engagement scolaire, bien-être personnel et autodétermination chez des étudiants à I'université. Canadian Journal of Behavioural Science, 42(2), 80.

Cavanaugh, J. K., \& Jacquemin, S. J. (2015). A large sample comparison of grade based student learning outcomes in online vs. face-to-face courses. Online Learning, 19(2), 1-8.

Chenard, P., Doray, P., Dussault, E. L., \& Ringuette, M. (2013). L'accessibilité aux études postsecondaires: un projet inachevé Presses de l'Université du Québec. 
Cheng, Y. M. (2014). Extending the expectation-confirmation model with quality and flow to explore nurses' continued blended e-learning intention. Information Technology \& People, 27(3), 230-258.

Chin, W. W. (2001). PLS-Graph User's Guide, Version 3.0. Houston, TX: C.T. Bauer College of Business, University of Houston.

Chiu, C. M., \& Wang, E. T. (2008). Understanding Web-based learning continuance intention: The role of subjective task value. Information and Management, 45(3), 194-201.

Cho, M. H. (2012). Online student orientation in higher education: A developmental study. Educational Technology Research and Development, 60(6), 1051-1069.

Choi, H. J., \& Park, J.-H. (2018). Testing a path-analytic model of adult dropout in online degree programs. Computers \& Education, 116, 130-138.

Croxton, R. A. (2014). The role of interactivity in student satisfaction and persistence in online learning. Journal of Online Learning and Teaching, 10(2), 314

DaDeppo, L. (2009). Integration factors related to the academic success and intent to persist of college students with learning disabilities. Learning Disabilities Research \& Practice, 24(3), 122-131.

Damnjanovic, V., Jednak, S., \& Mijatovic, I. (2015). Factors affecting the effectiveness and use of Moodle: students' perception. Interactive Learning Environments, 23(4), 496-514.

Downey, T. E. (2000). The application of continuous quality improvement models and methods to higher education: Can we learn from business? Proceedings of the Technological Education and National Development Conference (p.1-9), Abu-Dhabi, UAE. https://files.eric.ed.gov/fulltext/ED447291.pdf

Eliasquevici, M. K., da Seruffo, M. C., \& R., \& Resque, S. N. F. . (2017). Persistence in distance education: A study case using Bayesian network to understand retention. International Journal of Distance Education Technologies, 15(4), 61-78.

El-Masri, M., \& Tarhini, A. (2017). Factors affecting the adoption of e-learning systems in Qatar and USA: extending the unified theory of acceptance and use of technology 2 (UTAUT2). Educational Technology Research and Development, 65(3), 743-763.

Fabry, D. L. (2012). Using student online course evaluations to inform pedagogy. Journal of Research in Innovative Teaching, 5(1), 45-52.

Field, A. (2013). Discovering statistics using IBM SPSS statistics. Sage.

Fornell, C., \& Larcker, D. F. (1981). Evaluating structural equation models with unobservable variables and measurement error. Journal of Marketing Research, 18(1), 39-50.

Fredricks, J. A., Blumenfeld, P. C., \& Paris, A. H. (2004). School engagement: Potential of the concept, state of the evidence. Review of Educational Research, 74(1), 59-109.

Gaytan, J. (2015). Comparing faculty and student perceptions regarding factors that affect student retention in online education. American Journal of Distance Education, 29(1), 56-66.

Garratt-Reed, D., Roberts, L. D., \& Heritage, B. (2016). Grades, student satisfaction and retention in online and face-to-face introductory psychology units: A test of equivalency theory. Frontiers in Psychology, 7(673), 1-10.

Garrison, D. R. (2016). E-learning in the 21st Century: A Community of Inquiry Framework for Research and Practice. Routledge.

Garrison, D. R., Anderson, T., \& Archer, W. (2000). Critical inquiry in a text-based environment: Computer conferencing in higher education. The Internet and Higher Education, 2(2-3), 87-105.

Garrison, D. R., Anderson, T., \& Archer, W. (2001). Critical thinking and computer conferencing: A model and tool to assess cognitive presence. American Journal of Distance Education, 15(1), 7-23.

Gazza, E. A., \& Hunker, D. F. (2014). Facilitating student retention in online graduate nursing education programs: A review of the literature. Nurse Education Today, 34(7), 1125-1129.

Gefen, D., \& Straub, D. W. (2005). A Practical Guide to Factorial Validity Using PLS-Graph: Tutorial and Annotated Example. Communications of the Association for Information Systems, 16(1), 91-109.

Gerbing, D. W., \& Anderson, J. C. (1988). An updated paradigm for scale development incorporating unidi-mensionality and its assessment. Journal of Marketing Research, 25(2), 186-192.

Hachey, A. C., Wladis, C. W. \& Conway, K. M. (2014). Do prior online course outcomes provide more information than G.P.A. alone in predicting subsequent online course grades and retention? An observational study at an urban community college. Computers \& Education, 72, 59-67.

Hair, J. F., Hult, G. T. M., Ringle, C. M., \& Sarstedt, M. (2017). A primer on partial least squares structural equation modeling (PLS-SEM) (2nd ed.). SAGE.

Hair, J. F., Sarstedt, M., Ringle, C. M., \& Mena, J. A. (2012). An assessment of the use of partial least squares structural equation modeling in marketing research. Journal of the Academy of Marketing Science, 40(3), 414-433.

Halverson, L. R., \& Graham, C. R. (2019). Learner engagement in blended learning environments: A conceptual framework. Online Learning, $23,2$.

Heilporn, G., \& Lakhal, S. (2020). Investigating the reliability and validity of the community of inquiry framework: An analysis of categories within each presence. Computers \& Education, 145, 103712.

Heilporn, G., \& Lakhal, S. (2021). Environmental Facilitators and Barriers to Student Persistence in Online Courses: Reliability and Validity of New Scales. The Journal of Continuing Higher Education. https://doi.org/10.1080/07377363. 2020.1847972

Herbert, M. (2006). Staying the course: A study in online student satisfaction and retention. Online Journal of Distance Learning Administration, 9(4), 300-317.

Hsu, Y. C., Shiue, Y. M., \& Sheng, M. H. (2016, November). Continuous intention formation in E-tutoring system: Examining the roles of self-determined motivators, social and technological influences. In 2016 International Conference on Advanced Materials for Science and Engineering (ICAMSE) (pp. 188-191). IEEE.

Ice, P., Gibson, A. M., Boston, W., \& Becher, D. (2011). An exploration of differences between community of inquiry indicators in low and high disenrollment online courses. Journal of Asynchronous Learning Networks, 15(2), 44-69.

Islam, A. N. (2013). Investigating e-learning system usage outcomes in the university context. Computers \& Education, 69, 387-399.

Islam, A. N., \& Azad, N. (2015). Satisfaction and continuance with a learning management system: Comparing perceptions of educators and students. The International Journal of Information and Learning Technology, 32(2), 109-123. 
Joo, Y. J., Lim, K. Y., \& Kim, E. K. (2011). Online university students'satisfaction and persistence: Examining perceived level of presence, usefulness and ease of use as predictors in a structural model. Computers and Education, 57(2), 1654-1664.

Kahu, E. R. (2013). Framing student engagement in higher education. Studies in Higher Education, 38(5), 758-773.

Kauffman, H. (2015). A review of predictive factors of student success in and satisfaction with online learning. Research in Learning Technology, 23, 1.

Kember, D. (1989). A longitudinal-process model of drop-out from distance education. Journal of Higher Education, 60(3), 278-301.

Kember, D., Lai, T., Murphy, D., Siaw, I., \& Yuen, K. S. (1992). Student progress in distance education: Identification of explanatory constructs. British Journal of Educational Psychology, 62(3), 285-298.

Khechine, H., \& Lakhal, S. (2015). Effects of webinar use on student performance in higher education: What about grades. In Seventh International Conference on Education and New Learning Technologies (pp.329-337). Barcelona, Spain.

Khechine, H., \& Lakhal, S. (2018). Technology as a double-edged sword: From behavior prediction with UTAUT to students' outcomes considering personal characteristics. Journal of Information Technology Education, 17(1), 63-102.

Khechine, H., Lakhal, S., Bytha, A., \& Pascot, D. (2014). UTAUT model for blended learning. The role of gender and age in the intention to use webinars. Interdisciplinary journal of E-Learning and Learning objects, 10, 33-52.

Khechine, H., Lakhal, S., \& Ndjambou, P. (2016). A meta-analysis of the UTAUT model: Eleven years later. Canadian Journal of Administrative Sciences/Revue Canadienne des Sciences de I'Administration, 33(2), 138-152.

Kranzow, J. (2013). Faculty Leadership in Online Education: Structuring Courses to Impact Student Satisfaction and Persistence. MERLOT Journal of Online Learning and Teaching, 9(1), 131-139.

Kumar, P., Kumar, A., Palvia, S., \& Verma, S. (2019). Online business education research: Systematic analysis and a conceptual model. The International Journal of Management Education, 17(1), 26-35.

Kuo, Y. C., Walker, A. E., Belland, B. R., \& Schroder, K. E. (2013). A predictive study of student satisfaction in online education programs. The International Review of Research in Open and Distributed Learning, 14(1), 16-39.

Lakhal, S. (2019). Les déterminants technologiques de la persévérance des étudiants dans les cours à distance de niveau collégial: Les modalités de cours jouent-elles un rôle? Revue canadienne de l'apprentissage et de la technologiel Canadian Journal of Learning and Technology, 45(2), 1-26.

Lakhal, S., \& Bazinet, N. (2015, June). Technological factors explaining student dropout from online courses in higher education: A review. Dans EdMedia+ Innovate Learning (pp. 1806-1811). Association for the Advancement of Computing in Education (AACE), Montreal, Canada.

Lakhal, S., Khechine, H., \& Pascot, D. (2014, October). Academic Students' Satisfaction and Learning Outcomes in a HyFlex Course: Do Delivery Modes Matter? In Proceedings of world conference on e-learning in corporate, government, healthcare, and higher education 2014 (pp. 1936-1944), New Orleans, USA.

Lakhal, S., Khechine, H., \& Pascot, D. (2013). Student behavioural intentions to use desktop video conferencing in a distance course: integration of autonomy to the UTAUT model. Journal of Computing in Higher Education, 25(2), 93-121.

Lakhal, S., Khechine, H., \& Pascot, D. (2007, October). Evaluation of the effectiveness of podcasting in teaching and learning. In E-Learn: World Conference on E-Learning in Corporate, Government, Healthcare, and Higher Education (pp. 6181-6188). Association for the Advancement of Computing in Education (AACE), Quebec, Canada.

Lakhal, S., \& Khechine, H. (2016). Student intention to use desktop web-conferencing according to course delivery modes in higher education. The International Journal of Management Education, 14(2), 146-160.

Lakhal, S., \& Khechine, H. (2017). Relating personality (Big Five) to the core constructs of the Unified Theory of Acceptance and Use of Technology. Journal of Computers in Education, 4(3), 251-282.

Lakhal, S., \& Khechine, H. (2021). Technological factors of students' persistence in online courses in higher education: The moderating role of gender, age and prior online course experience. Education and Information Technologies. https://doi.org/10.1007/s10639-020-10407-w

Laurie, E. C., Kim, J. H., José, P. W., \& Rob, L. M. (2020). Predicting and resolving non-completion in higher (online) education-A literature review. Educational Research Review, 29, 100313.

Lee, K. (2017). Rethinking the accessibility of online higher education: A historical review. The Internet and Higher Education, 33, 15-23.

Lee, Y., \& Choi, J. (2011). A review of online course dropout research: implications for practice and future research. Educational Technology Research and Development, 59(5), 593-618.

Levy, Y. (2007). Comparing dropouts and persistence in e-learning courses. Computers and education, 48(2), 185-204.

Lin, K. M. (2011). e-Learning continuance intention: Moderating effects of user e-learning experience. Computers and Education, 56(2), 515-526.

Lin, K. M., Chen, N. S., \& Fang, K. (2011). Understanding e-learning continuance intention: a negative critical incidents perspective. Behaviour \& Information Technology, 30(1), 77-89.

Lin, P. C., Lu, H. K., \& Liu, C. (2013). Towards an education behavioral intention model for e-learning systems: an extension of UTAUT. Journal of Theoretical and Applied Information Technology, 47(3), 1120-1127.

Loyd, B. H., \& Gressard, C. (1984). Reliability and factorial validity of computer attitude scales. Educational and psychological measurement, 44(2), 501-505.

Loyd, B. H., Loyd, D. E., \& Gressard, C. P. (1987). Gender and computer experience as factors in the computer attitudes of middle school students. The Journal of Early Adolescence, 7(1), 13-19.

Mandernach, B. J. (2015). Assessment of Student Engagement in Higher Education: A Synthesis of Literature and Assessment Tools. International Journal of Learning, Teaching and Educational Research, 12(2), 1-14.

Mahmodi, M., \& Ebrahimzade, I. (2015). The analysis of Iranian students' persistence in online education. International Review of Research in Open and Distributed Learning, 16(1), 98-119.

Mcilroy, D., Sadler, C., \& Boojawon, N. (2007). Computer phobia and computer self-efficacy: their association with undergraduates' use of university computer facilities. Computers in Human Behavior, 23(3), 1285-1299. 
Mohammadyari, S., \& Singh, H. (2015). Understanding the effect of e-learning on individual performance: The role of digital literacy. Computers \& Education, 82, 11-25.

Muljana, P. S., \& Luo, T. (2019). Factors contributing to student retention in online learning and recommended strategies for improvement: A systematic literature review. Journal of Information Technology Education: Research, 18, 19-57.

Müller, T. (2008). Persistence of women in online degree-completion programs. International Review of Research in Open and Distance Learning, 9(2), 1-18.

Myers, M. P., \& Schiltz, P. M. (2012). Use of Elluminate in online teaching of statistics in the health sciences. Journal of Research in Innovative Teaching, 5(1), 53-62.

Nunnally, J. C. (1978). Psychometric theory (2nd ed.). Mc Graw Hill.

Ouyang, Y., Tang, C., Rong, W., Zhang, L., Yin, C., \& Xiong, Z. (2017). Task-technology fit aware expectation-confirmation model towards understanding of MOOCs continued usage intention. Proceedings of the 50th Hawaii International Conference on System Sciences, (p. 174-183), Hawai, USA.

Park, J. (2007). Factors related to learner dropout in online learning. In Nafukho, F. M., Chermack, T. H. et Graham, C. M. (Eds.). Proceedings of the 2007 Academy of Human Resource Development Annual Conference, 25-1-25-8. Indianapolis, IN: AHRD.

Park, J. H., \& Choi, H. J. (2009). Factors influencing adult learners' decision to drop out or persist in online learning. Educational Technology and Society, 12(4), 207-217.

Prensky, M. (2001). Digital natives, digital immigrants part 1. On the horizon, 9(5), 1-6.

Rachman, S. (1998). Anxiety. Psychology Press.

Riggert, S. C., Boyle, M., \& Petrosko, J. M. (2006). Student employment and higher education: Empiricism and contradiction. Review of Educational Research, 76(1), 63-92.

Rodríguez-Ardura, I., \& Meseguer-Artola, A. (2016). E-learning continuance: The impact of interactivity and the mediating role of imagery, presence and flow. Information \& Management, 53(4), 504-516.

Roland, N., Frenay, M., \& Boudrenghien, G. (2018). Understanding academic persistence through the theory of planned behavior: Normative factors under investigation. Journal of College Student Retention: Research, Theory \& Practice, 20(2), 215-235.

Roy, N., Gareau, A., \& Poellhuber, B. (2018). The Digital Natives in Education: Issues and Practices. Canadian Journal of Learning and Technology/La revue canadienne de l'apprentissage et de la technologie, 44(1), 1-21.

Rovai, A. P. (2003). In search of higher persistence rates in distance education online programs. The Internet and Higher Education, 6(1), 1-16.

Schmitz, J., Frenay, M., Neuville, S., Boudrenghien, G., Wertz, V., Noël, B., \& Eccles, J. (2010). Study of three key factors to understand academic persistence. Revue française de pédagogie, 172, 43-61.

Shin, N. (2003). Transactional presence as a critical predictor of success in distance learning. Distance education, 24(1), 69-86.

Stiller, K. D., \& Köster, A. (2016). Learner attrition in an advanced vocational online training: the role of computer attitude, computer anxiety, and online learning experience. European Journal of Open, Distance and E-Learning, 19(2), 1-14.

Stoessel, K., Ihme, T. A., Barbarino, M. L., Fisseler, B., \& Stürmer, S. (2015). Sociodemographic diversity and distance education: Who drops out from academic programs and why? Research in Higher Education, 56(3), 228-246.

Strevy, S. (2009). Persistence of students in RNBS completion online programs. Ph.D. Dissertation, Bloomington, IN: Indiana University.

Sultan, S., \& Hagger, M. (2013). Psychological and socio-demographic correlates of academic performance distinguishing completers and non-completers in distance education. Journal on Educational Psychology, 7(2), 23-29.

Sun, P. C., Tsai, R. J., Finger, G., Chen, Y. Y., \& Yeh, D. (2008). What drives a successful e-Learning? An empirical investigation of the critical factors influencing learner satisfaction. Computers \& education, 50(4), 1183-1202.

Šumak, B., Heričko, M., \& Pušnik, M. (2011). A meta-analysis of e-learning technology acceptance: The role of user types and e-learning technology types. Computers in Human Behavior, 27(6), 2067-2077.

Tarhini, A., \& Masa'deh, R. E., Al-Busaidi, K. A., Mohammed, A. B., \& Maqableh, M. . (2017). Factors influencing students' adoption of e-learning: A structural equation modeling approach. Journal of International Education in Business, 10(2), 164-182.

Téo, T., \& Wong, S. L. (2013). Modeling key drivers of E-learning satisfaction among student teachers. Journal of Educational Computing Research, 48(1), 71-95.

Venkatesh, V., Morris, M. G., Davis, G. B., \& Davis, F. D. (2003). User acceptance of information technology: Toward a unified view. MIS Quarterly, 27(3), 425-478.

Wang, S.-K., \& Hsu, H.-Y. (2008). Use of the webinar tool to support training: the effects of webinar-learning implementation from trainers' perspective. Journal of Online Interactive Learning, 7(3), 175-194.

Watts, L. (2016). Synchronous and asynchronous communication in distance learning: A review of the literature. Quarterly Review of Distance Education, 17(1), 23-32.

Wu, B., \& Zhang, C. (2014). Empirical study on continuance intentions towards E-Learning 2.0 systems. Behaviour \& Information Technology, 33(10), 1027-1038.

Xavier, M., \& Meneses, J. (2020). Dropout in Online Higher Education: A scoping review from 2014 to 2018. Barcelona, Spain: eLearn Center, Universitat Oberta de Catalunya.

Yang, D., Baldwin, S., \& Snelson, C. (2017a). Persistence factors revealed: students' reflections on completing a fully online program. Distance Education, 38(1), 23-36.

Yang, M., Shao, Z., Liu, Q., \& Liu, C. (2017b). Understanding the quality factors that influence the continuance intention of students toward participation in MOOCs. Educational Technology Research and Development, 65(5), 1195-1214.

Yoo, S. J., \& Huang, W. D. (2013). Engaging online adult learners in higher education: Motivational factors impacted by gender, age, and prior experiences. The Journal of Continuing Higher Education, 61(3), 151-164.

You, J. W. (2018). Testing the three-way interaction effect of academic stress, academic self-efficacy, and task value on persistence in learning among Korean college students. Higher Education, 76(5), 921-935. 
Zhang, Y. (2000). Using the Internet for survey research: A case study. Journal of the American Society for Information Science, 51(1), 57-68.

\section{Publisher's Note}

Springer Nature remains neutral with regard to jurisdictional claims in published maps and institutional affiliations.

Submit your manuscript to a SpringerOpen ${ }^{\circ}$ journal and benefit from:

- Convenient online submission

- Rigorous peer review

- Open access: articles freely available online

- High visibility within the field

- Retaining the copyright to your article

Submit your next manuscript at $\boldsymbol{\nabla}$ springeropen.com 